CAICIUNA-BORON RELATIONSHIPS IN THE NUTRITION OF CORN AND THE DISTRIBUTION OF THESE ELEMENTS IN THE PLANTS

by Ernesto Fernández-IMedina and John W. Shive

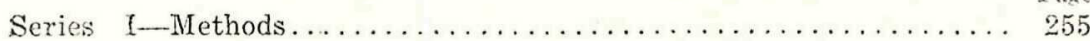

Results.......................... 259

Series II-Methods............................. 259

Results......................... 271

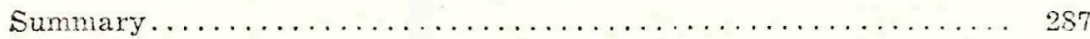

Acknowledgment $\ldots \ldots \ldots \ldots \ldots \ldots \ldots \ldots \ldots \ldots \ldots \ldots \ldots \ldots \ldots \ldots \ldots$

Bibliography. ....................... 289 


\title{
CALCIUM-BORON RELATIONSHIPS IN THE NUTRITION OF CORN AND THE DISTRIBUTION OF THESE ELEMENTS IN THE PLANT ${ }^{1}$
}

\author{
Ernesto Hernández-Medina ${ }^{2}$ and John W. Shive ${ }^{3}$
}

The literature dealing with the inorganic nutrition of plants reveals that great attention has been given to the important role that the so-called trace elements play in the metabolic activities of different species of plants. Boron is one of these elements that has received particular attention in this regard. Both qualitative evidence and quantitative evidence $(23,28,32,33,42,43,50)$ show that this element is indispensable for normal growth and development of plants and, therefore, it may be added to the previous list of essential elements (38).

Soils naturally low or deficient in boron have been reported ( 35 , 48 ) in over half of the 48 states, with large areas occurring along the Atlantic coastal plain, in the Great Lakes region, and in the Pacific Northwest. If boron is not applied in usual fertilizer practices to such deficient or sub-deficient soils metabolic disturbances of the plants are likely to result in abnormal plant development as evidenced by the appearance of boron deficiency symptons and reduced crop production. Naftel $(25,26,27)$ was one of several investigators $(5,20,51)$ to show that liming of soils naturally low or deficient in boron is likely to cause an initiation or accentuation of boron deficiency symptoms in plants growing thereon. He found that in soils low or deficient in boron, liming decreased the water-soluble boron of the soil. On the other hand, White-Stevens (49) found that the effective level of boron in the fertilizer mixture for controlling boron deficieney in deficient soils depended upon the kind of crop grown. This suggests that care should be exercised in the application of fertilizer in soils lacking or low in boron.

The fact that it is virtually impossible $(36,38)$ to distinguish externally between boron and calcium deficiency symptoms has sug.

1 Rutgers University, Department of Plant Physiology, New Brunswick, New Jersey. Journal Series paper, New Jersey Agricultural Experiment Station. Part of a thesis submitted to the facuity of the Graduate School of Rutgers University in partial fulfillment of the requirements for the deree of Master of Science.

${ }^{2}$ Assistant Plant Physiologist, Agricultural Experiment Station of the University of Puerto Rico, Río Piedras, Puerto liico.

${ }^{3}$ Formerly Professor and Head of Department of Plant Physiology, Rutgers University and Plant Physiologist of the New Jersey Agricultural Experiment Station. Now Professor Emeritus of Rutgers University. 
gested a possible relation between these two clements in plant nutrition. Anong the first investigators to suggest a possible association between boron and ealeium in the plant were Brenchley and Warington $(3,41)$ using the broad bean as an indicator plant. They suggested that boron either enables the plant to absorb more calcium in a given period of time or permits it to be used more efficiently once it is absorbed by the plant. In the absenee of boron, calcium in the roots was not utilized effectively. Later work by Marsh and Shive with corn (17) corroborated the findings of Brenchley and Warington. They found that the presence of an appropriate amount of available boron in the plant tended to maintain, in an available condition, the calcium absorbed even if no additional calcium was supplied to the plant. Evidence is also presented which demonstrates that the boron content of the culture solution did not greatly influenee rates of calcium absorption by the plants. In an annual report of the New Jersey Agrienltural Experiment Station the suggestion is made that boron may influence the normal metabolism of calcium in plants (29). The suggestion is sustained by the fact that no calcium was found or detected in the cell sap in the meristems of boron deficient cotton plants. Results obtained by Lowenhaupt, working with sunflower (16), with reference to calcium content of tissues are in agreement with the view that there is a relationship between the boron available to the plant and the utilization of calcium. Haas (11) working with citrus and ralnuts found no evidence in the leaves of any relationship between the soluble boron and the soluble calcium in the same tissues; while Muhr (24) working with sugar beets, radishes, chickory, turnip, barley, wheat, dandelions, mangels, rutabaga and corn, and Fill and Grant (12) with turnips found that tissue of plants inadequately supplied with boron contained, in general, a higher percentage of calcium than the tissue srown with sufficient boron. Still, there is a diversity of opinion among investigators as to the determinative role of boron in the aceumulation of calcium in the plant. Haas (10) working with citrus found that the percentage of total calcium that was water soluble was higher in leaves of plants which received large quantities of boron in the substrate than in the leaves of plants receiving lower levels of boron in the nutrient medium. On the other hand, Holley and Dulin (13), Morris (22), and Dmitriev (7) furnished evidence to demonstrate that the presence or absence of boron in the nutrient media had no influence on the quantity of calcium in the plant tissue analyzed. As lias been indicated (31) some disagreement may be due to the use of different species of plants, dif- 
fercnt growing media (sand and water cultures, in some cases; soil, in others) varying (limatic conditions, and differences in the boron concentrations involved.

Later work $(4,6,14)$ hiss furinshed evidence that a definite balance exists between the calcitm and boron content of healthy tomato, tobaceo and oat plants. Brennan (4) has indicated that normal tomato plants have an intermediate numerical ratio of total calcium to total boron whereas boron deficient plants and boron toxic plants have abnormally high and abnormally low ratios, respectively.

The purpose of this investigation was to study further the calciumboron relationship in the corn plant and to determine the distribution of these elements in this monocotyledon.

\section{SERIES I}

METHODS

Cultural methods--This experiment was the first of two series and was started on October 16, 1945. The plants were grown in sand culture. Corn seeds of Rutgers Hybrid No. 2 were used. They were selected for uniformity in shape and size and were sowed directly in purified sand in 9 inch highly glazed pots. The sand was previously washed with tap water, then treated with 2 per cent sodium hydroxide and left overnight. Following this, it was flushed with distilled water, treated with 2 per cent liydrochloric acid and again left overnight, after which it was completely flushed with distilled water until free from chloride ions as determined by the silver nitrate test. This sand treatment was necessary to remove any materials which might furnish boron and also to free the sand from other nutrients. Four seeds were planted in each pot and the sand was flushed with a dilute nutrient solution of the following composition: $\mathrm{KH}_{2} \mathrm{PO}_{4}, 0.0016 \mathrm{M}$; $\mathrm{NaNO}_{3}, 0.0038 \mathrm{M}$.; $\mathrm{MgSO}_{4}, 0.0028 \mathrm{M}$; $\mathrm{CaCl}_{2}, 0.0025 \mathrm{M}$. with the usual traces of iron, zine and manganese but with no boron. Four days after germination the best three seedlings were left for treatment. The rejected seedling was removed by first flushing the sand with distilled water and then gently pulling it out with its entire root system. The cultures were maintained on the diluted culture solution for a week to develop uniform plants before nutrient treatments were started. At the end of this period all plants appeared vigorous and fairly uniform and the calcium-boron nutrient treatments were begun and maintained for 64 days, using the continuous solution renewal method of Shive and Stahl $(39,40)$. Approximately two liters of nutrient solution per day were used for each culture containing three plants. 
In this experiment there was a total of forty-eight cultures, which were divided into six groups of eight cultures each. Each group was grown at a different level of calcium, as follows: 5.0, 10.0, 50.0, $100.0,250.0$, and 500.0 p.p.m. Each of the eight cultures in a given calcium level received boron in eight different concentrations. The levels of boron used were as follows: $0.0,0.001,0.01,0.10,0.25,5.0$, 10.0, and 20.0 p.p.m. Figure 1 ilustrates the plan of the experiment the number on each block representing culture numbers. The composition of the culture solutions with the different levels of calcium used with each of the eight boron levels is presented in table 1 . Salts of analytical grade were used without further repurification. Boron was supplied in the form of boric acid. The ammonium sulfate was used to aid in the prevention of iron-deficiency chlorosis.

At the end of the experimental period, on December 28, when definite symptoms of boron deficiency and toxicity occurred on plants receiving deficient and very high nutrient levels of boron respectively, the plants on the different treatments were harvested. After green and dry weights of the tops had been obtained, the plants were cut with a stainless steel knife into small pieces which were thoroughly mixed so that representative samples could be obtained for analysis.

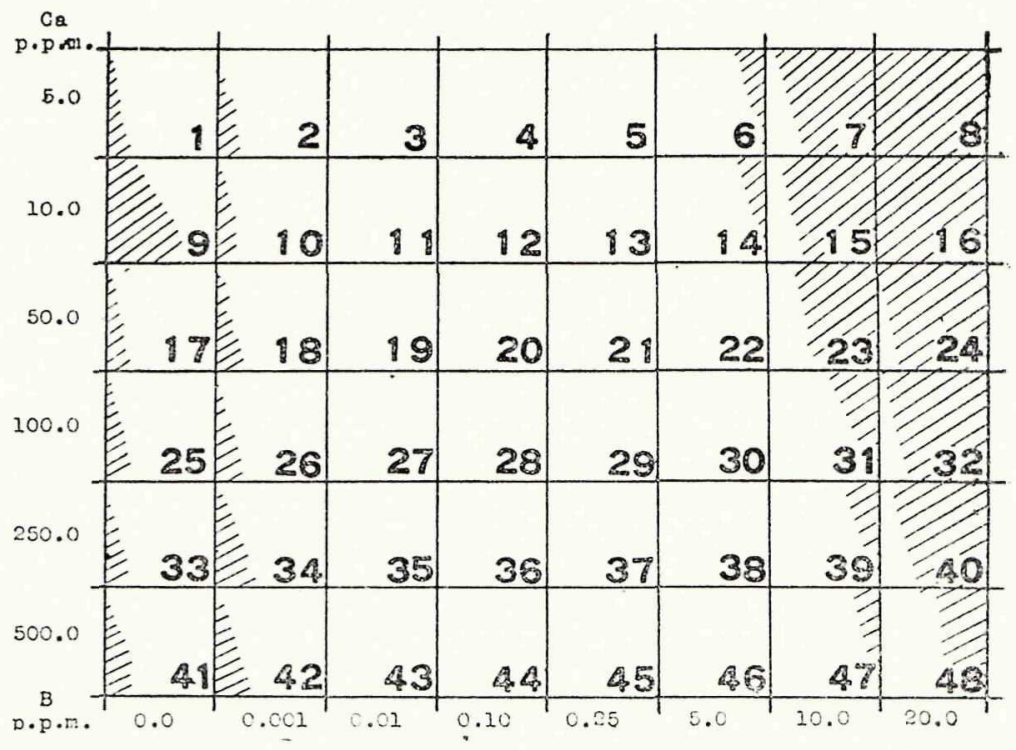

FIG. 1.-Diagram showing calcium and boron treatments and general experimental plan. Relative proportion of shaded area of each block at the lef't denotes relative degree of boron deficiency symptoms, those at the right boron toxicity symptoms. 
TABLE No. 1

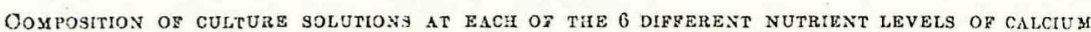
USED WITH EACH OF 8 DIFFERENT BORON CONCENTRATIONS OF $0.0,0.001,0.01,0.10$, $0.25,5.0,10.0$, AND 20.0 P. P. M.*

\begin{tabular}{|c|c|c|c|c|c|c|c|c|}
\hline \multirow[b]{2}{*}{ Culture Numbers } & \multirow{2}{*}{$\begin{array}{l}\text { Calcium } \\
\text { Levels }\end{array}$} & \multicolumn{7}{|c|}{ Molar Concentration of Salts } \\
\hline & & $\mathrm{KH}_{2} \mathrm{PO}_{4}$ & $\mathrm{~K}_{2} \mathrm{SO}_{4}$ & $\mathrm{NaNO}_{3}$ & $\mathrm{MgSO}_{4}$ & $\mathrm{CaCl}_{2}$ & $\mathrm{CaSO}_{4}$ & $\begin{array}{c}\left(\mathrm{NH}_{4}\right)^{2} \\
\mathrm{SO}_{4}\end{array}$ \\
\hline 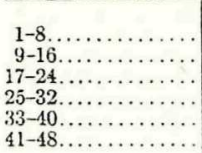 & $\begin{array}{c}\text { p. p. m. } \\
5 \\
10 \\
50 \\
100 \\
250 \\
500\end{array}$ & $\begin{array}{l}.00113 \\
.00113 \\
.00113 \\
.00113 \\
.00113 \\
.00113\end{array}$ & $\begin{array}{l}.00113 \\
.00113 \\
.00113 \\
.00113 \\
.00113 \\
.00113\end{array}$ & $\begin{array}{l}.0085 \\
.0185 \\
.0035 \\
.0085 \\
.0055 \\
.0055\end{array}$ & $\begin{array}{l}.00113 \\
.00113 \\
.00113 \\
.00113 \\
.00113 \\
.00113\end{array}$ & $\begin{array}{l}.000125 \\
.00925 \\
.00125 \\
.0025 \\
.00625 \\
.00625\end{array}$ & 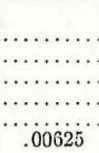 & $\begin{array}{l}.0004 \\
.0004 \\
.0004 \\
.0004 \\
.0904 \\
.0001\end{array}$ \\
\hline
\end{tabular}

* Trace Elesents:- Each nutrient solution contained 1 p. p. m. iron, 0.5 p .p. m. zinc, anc $025 \mathrm{p} . \mathrm{p} . \mathrm{m}$. manganese used in the form of sulfates.

In order to determine the soluble boron and calcium in the plant tissue, a 50-gram sample of fresh tissue from each culture was frozen in a refrigerator immediately at time of harvest and kept at approximately minus $18^{\circ} \mathrm{C}$ until ready for analysis. In addition, 100-gram samples of fresh tissue were weighed and dried as described below to be used in the determinations for total boron and total calcium in each aliquot.

At the time of harvest one of the three plants from a culture receiving a high and a low boron level in each calcium series was harvested separately and fractionated into top leaves, middle stem and lower stem in order to make a preliminary study of the distribution of the total boron and calcium in these portions of the plant. The fraction designated as "top leaves" consisted of the leaves extending above and including the apical meristem; the "middle stem" fraction consisted of the culm tissue including leaf sheath but without blades extending from the base of the apical meristem to the node second removed from the sand surface; the "lower stem" fraction consisted of the lower two nodes and internodes of the eulm including leaf sheaths but without blade tissue.

Chemical Methods-Dry weights of the 100-gram samples of green tissue taken for analysis at the time of harvest were obtained after oven drying at $70^{\circ} \mathrm{C}$ for 48 hours. The dried tissue was then ground in a semi-micro Wiley mill to pass a 40 mesh screen, after which 2-gram samples were weighed into porcelain erucibles and ignited in a muffle furnace starting at room temperature and gradually raising the temperature to $600^{\circ} \mathrm{C}$. The samples were held at this temperature for approximately 6 hours which resulted in complete ashing. The ash was dissolved in $20 \mathrm{ml}$. of $(1+4) \mathrm{HCl}$, transferred 
to a $100 \mathrm{ml}$. volumetric flask and made to volume. Aliquots of this solution were then taken for determination of total boron and total calcium.

For the determination of tissue contents of soluble boron and soluble calcium, the frozen 50-gram tissue samples were thawed and then placed in a piece of muslin of suitable size fitted in a nickel plated steel cylinder 5.71 centimeters inside diameter, covered with $40 \mathrm{ml}$. of distilled water, and subjected to a pressure of 2500 pounds per square inch for one minute in a Carver Press. The press cake was washed twice more with $40 \mathrm{ml}$. of distilled water and subjected to the same pressure but after the last washing the pressure was maintained for two minutes. The extracted plant juices and washings were passed through a quantitative Whatman number 5 filter paper using suction. The press cake was then remored from the muslin and together with the filter paper was oven-dried at $70^{\circ} \mathrm{C}$ for 48 hours. After drying, press cake and filter paper were ignited in a mufile furnace and the ash was dissolved and the solution made to volume as previously described. Aliquots of these samples were taken for the determinations of boron and calcium, respectively. Soluble boron and soluble calcium contents of the tissue were determined by the differences between the analytical values of these two elements in the unextracted sample and the extracted press cake.

In this work the soluble portions of boron and of calcium are considered to be those which were extracted from the tissue samples under pressure by the method described and these soluble portions are also considered to be the active portions in the tissue at least. at the time of harvest. Those portions of the calcium and boron which remain in the plant tissue in the press cake after extraction of the juices by the above method are considered to be the insoluble and inactive portions.

The official micro-method of the Association of Official Agricultural Chemists (1) with a few minor changes was used for the calcium determinations. Since it is not necessary to remove the silicon dioxide, this step was omitted (21). Coprecipitation of the silicon dioxide with ealcium oxalate does not interfere in the titration of the oxalate ions by the permanganate ions. To obtain reater accuracy in the results $0.01 \mathrm{~N}$ KMInO, was used for titrating the oxalate ion instead of $0.02 \mathrm{~N}$ solution recommended in the official method.

The Berger and Truog (2) colorimetric method was used for the quantitative determination of boron with modifications similar to those of Narsh and Shive (17) except that $10 \mathrm{ml}$. quantities of sul- 
furic acid-quinalizarin reagent were used with $1 \mathrm{ml}$. of the test solutions instead of the $50 \mathrm{ml}$. quantities used by Marsh and Shive. The $50 \mathrm{ml}$ Nessler tubes uscd for color comparison of standards and test solutions were kept tightly closed during the determinations. Sulfuric acid, 95.5 per cent by weight, was used in this method instead of the 98 per cent acid employed by Berger and Truog.

\section{Results}

Character of Plants aficr Treatment.-The relative intensities of the visible symptoms of metabolic disorder resulting respectively from deficient and excess nutrient concentrations of boron in the culture solution are represented by the shaded areas in figure 1 . All the plants at the two lowest boron levels, 0.00 and 0.001 p.p.m. exhibited boron deficiency symptoms. However, as is indicated in figure 1, none of these boron deficient plants were very seriously injured and, moreover, no definite relation is observable between severity of boron deficient symptoms and relative calcium concentrations of the substrate. The injury due to boron deficiency which oceurred in boron deficient cultures in this experiment ranged from slight to medium intensity and was not so severe as that in similar nutrient treatments in the experiment to be reported later in this paper. The boron deficieney symptoms were characterized by the appearance of elongated white transparent interveinal stripes on the newly formed leaves (44) and were similar but not quite so severe as those on leaves of plants shown in figure 2, which were grown in a subsequent experiment. The roots of the boron defieient plants were slightly brown, and the root systems were not so extensive as those of plants receiving boron. These symptoms were especially severe at the low calcium levels probably as a result of both boron and calcium deficiencies.

It has been reported (46) that under the short day conditions of spring and autumn the onset of boron deficiency symptoms is delayed as compared with long day conditions of summer. Since this experiment was run during the fall season it is possible that the short length of day may account for the fact that the boron deficiency symptoms were not so severe as those which developed in boron deficient cultures grown in the subsequent experiment conducted under the long day conditions of late spring. No distortion or injury was observed in apical meristems of boron deficient plants.

Figure 1 shows that slight boron toxicity symptoms appeared in cultures number 6 and number 14 receiving 5.0 p.p.m. boron at the two lowest calcium levels. Plants in other cultures grown at this boron level cxhibited no toxicity symptoms. At the boron concentrations 
of 10.0 p.p.m., boron toxicity symptoms were more severe than at 5.0 p.r. and appeared to some extent in plants at all calcium. levels. At the boron level of 20.0 p.p.m. the metabolic disturbances due to the high boron concentration were most pronounced and were especially severe at the three lowest calcium lcvels.

The plants grown at 20.0 p.p.m. boron and with 5.0 p.p.m. of ealcium (figure 3) showed more serious amptoms of boron toxicity than the plants grown at the saine boron level but with 500.0 p.p.m. calcium (figure 4). Boron toxicity symptoms cousisted of stunted

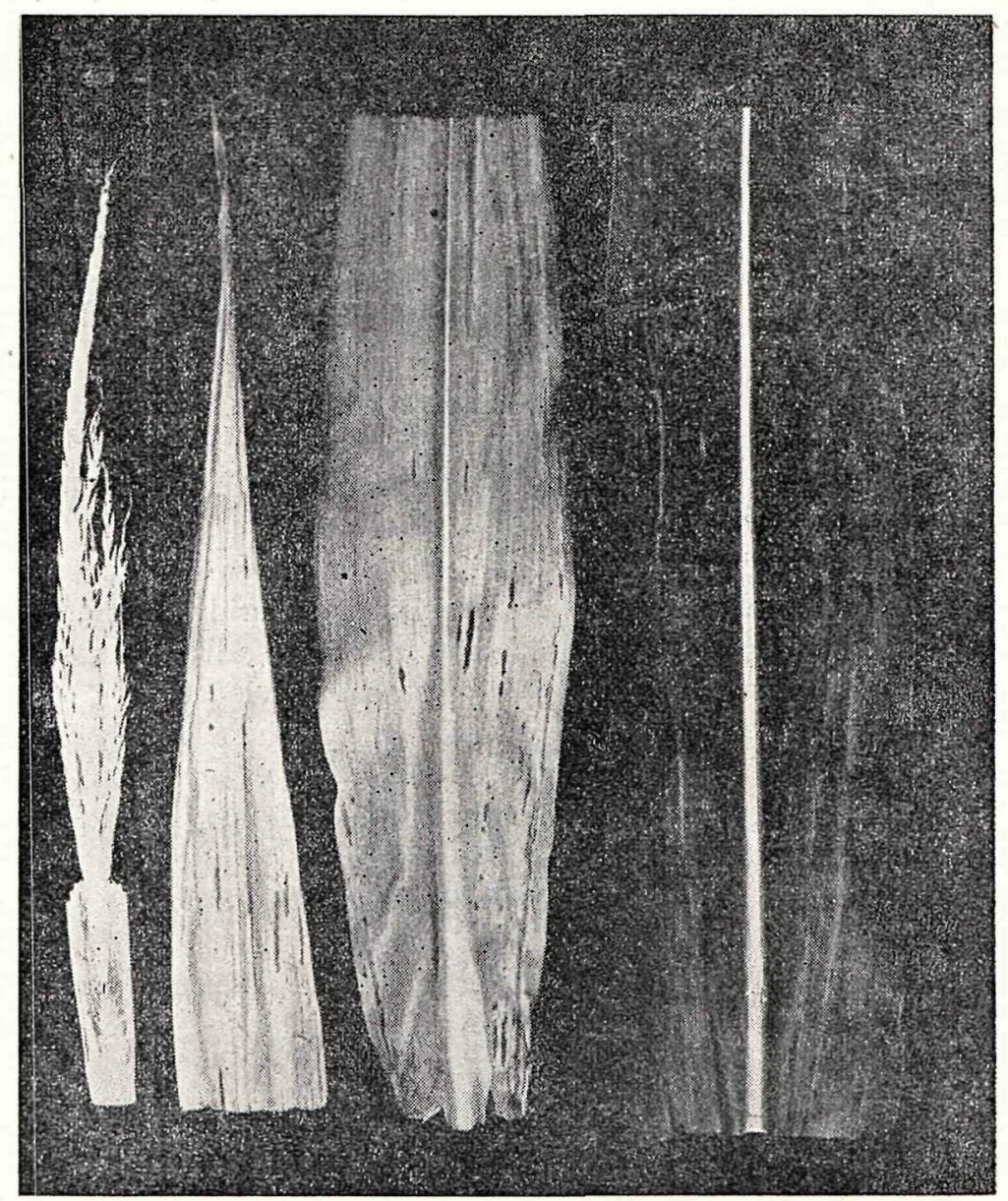

FIG. 2.-Typical boron deficiency symptoms of growing point and top leaves of com pian' grown at inutrient levels of 250.0 p.p.m. calcium and 0.001. p.p.m. boron. 
growth, pale yellow-green eolor of the youngest leaves with yellow colored, dying and dead marginal tissue appearing largely on the older leaves. Typical boron toxicity symptoms are shown in figure 5 on the leaves of plants grown in a subsecuent experiment. The root system of boron toxic plints were relatively small and the roots were brown in color. The appearance of these root systems was similar to those of plants reciving similar treatments and grown in a subsequent experimcint.

Calcium deficieney sympins were observed to some extent in the younger leaves of plants receiving 5.0 and 10.0 p.p.m. calcium. These symptoms consisted of clistortions, brealss, and colorless areas

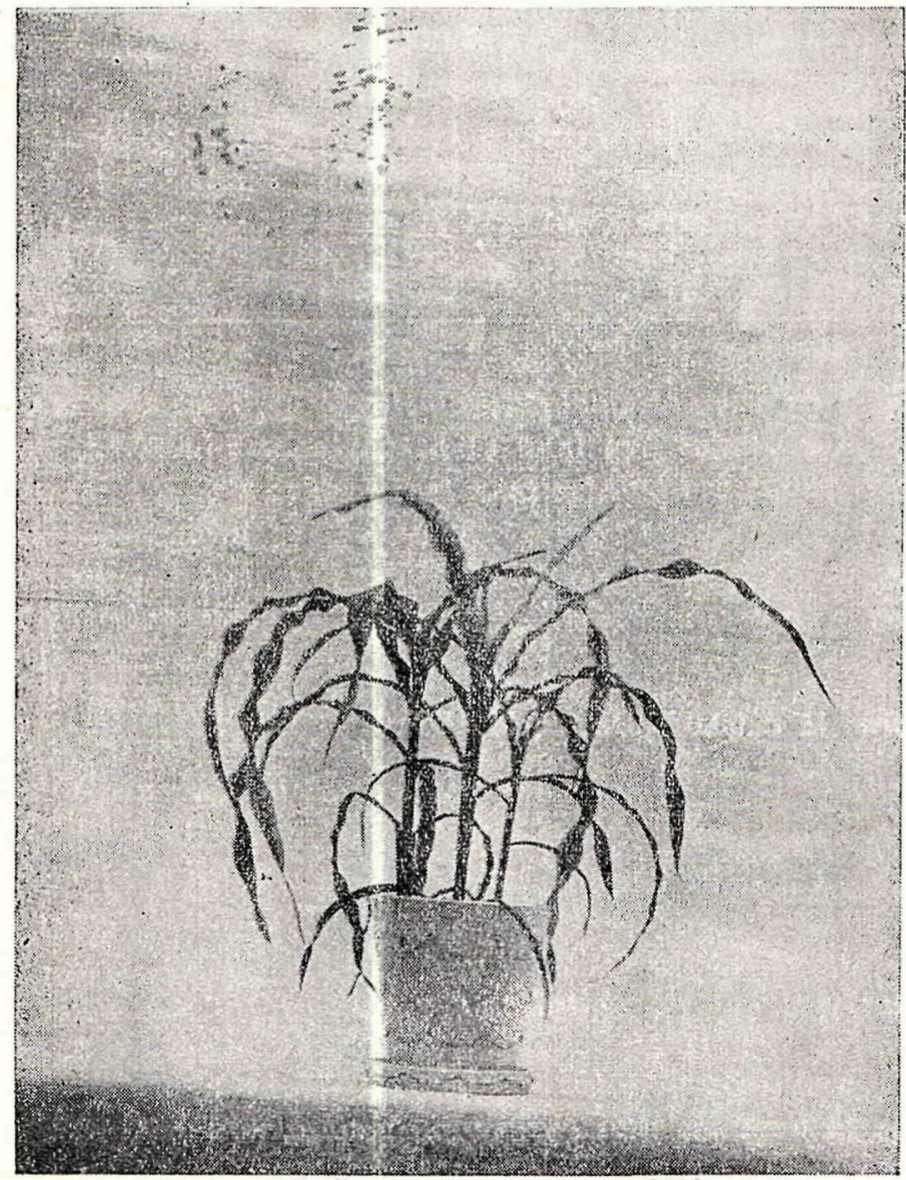

FIG. 3.-Corn plants grown in culture number 8 at nutrient levels of 5.0 p.p.m. calcium and 20.0 p.p.m. boron. 
of tissue on the margins and tips of the leaves. These calcium deficiency symptoms are similar to, but not so serious as those which occurred on leaves of plants grown in a subsequent experiment. (Figure 6).

With regard to green and dry weights of the whole tops of the plants grown with the various calcium-boron nutrient levels it was found that with few exceptions green and dry weights increased as the calcium concentration of the substrate increased at any given boron level. The green and dry weights of the plants receiving the highest nutrient levels of boron 5.0, 10.0 and 20.0 p.p.m. within

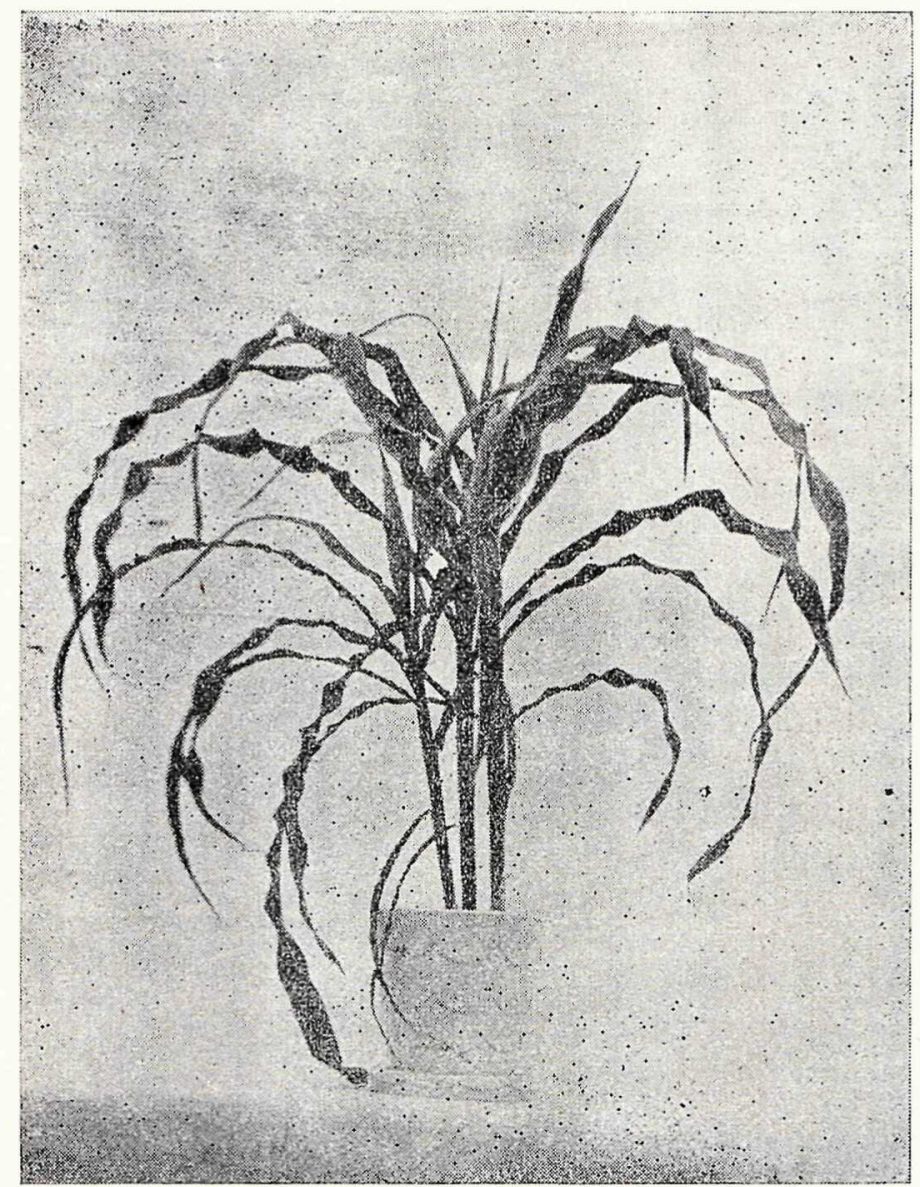

FIG. 4.-Corn plants grown in culture number 48 at nutrient levels of 500.0 p.p.m. calcium and 20.0 p.p.m. boron showing mild symptoms of boron toxicity. 
a given calcium level were considerably lower than the weights of those plants receiving lower nutrient levels of boron.

Results of Chemical Analyses.--The results of quantitative analyses for boron and calcium contents of the tissues, both total and soluble, are presented in table 2. It appears from the analytical data that both total boron and soluble boror at any given nutrient level of boron are more or less independent of the calcium concentration in

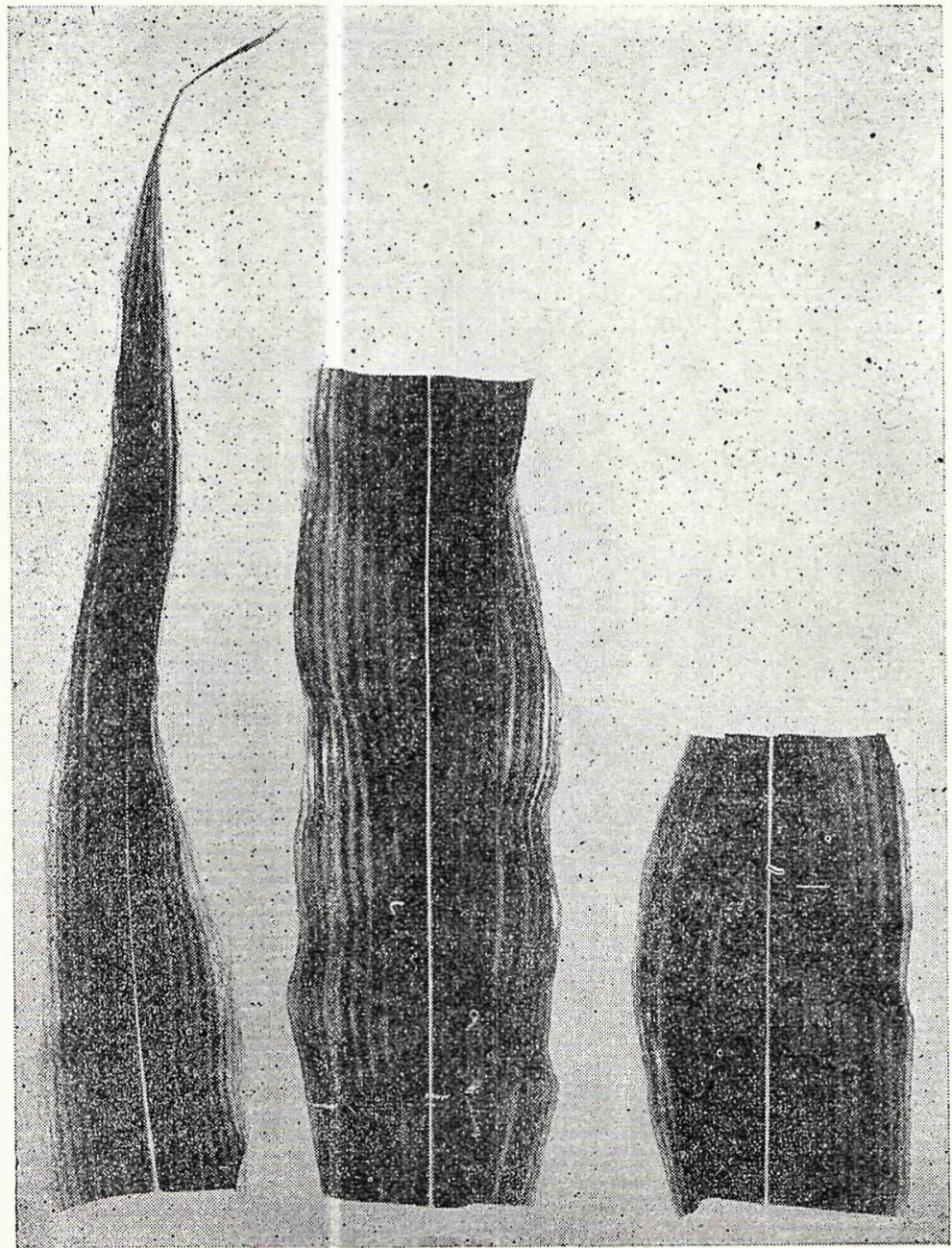

FIG. 5.-Typical boron toxicity symptoms of lower leaves of corn piant grown at mutrient levels of 100.0 p.p.m. calcium and 20.0 p.p.m. boron. 
the substrate. However, the plants receiving highest nutrient concentrations of boron (20.0 p.p.m.) contained somewhat lower tissue contents of boron, both total and soluble, when grown at the highest calcium level (500.0 p.p.m.) than plants grown at equivalent boron level but at lower ealcium concentrations. This suggests that boron aceumulation by the plant was modified in some way at the highest ealcium level. These results support the qualitative observations wherein boron toxicity symptoms of plants receiving the highest

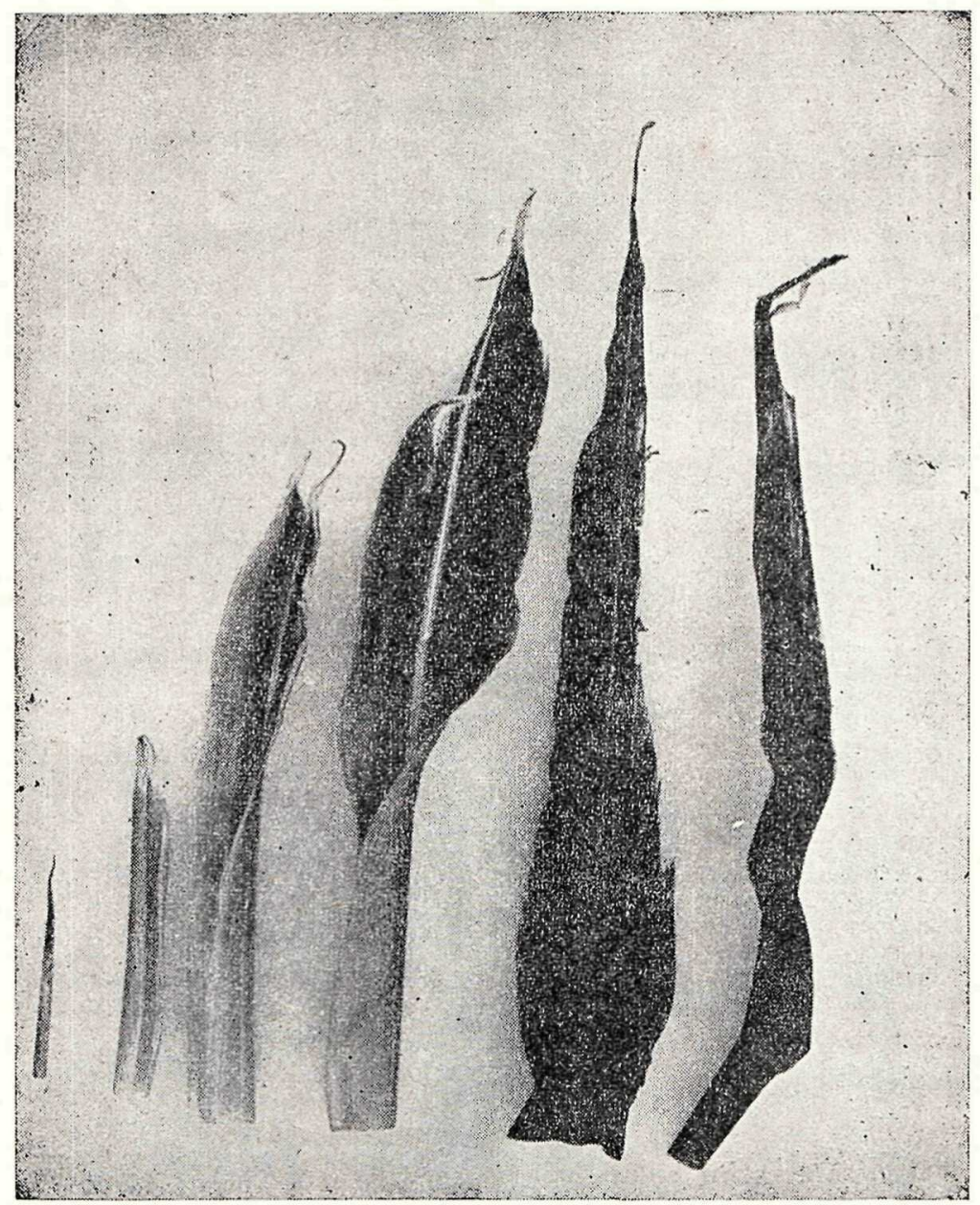

FIG. 6.-Leaves showing well defined calcium deficiency symptoms of corn plant grown at nutrient levels of 5.0 p.p.m. calcium and 0.25 p.p.m. boron. 
TABLE NO. 2

TOTAL AND SOLUBLE CALCIUM AND BORON IN MILLIGRAMS PER GRAM DRY TISSUE OF WHOLE TOPS OF CORN PLANTS OF SERIES I

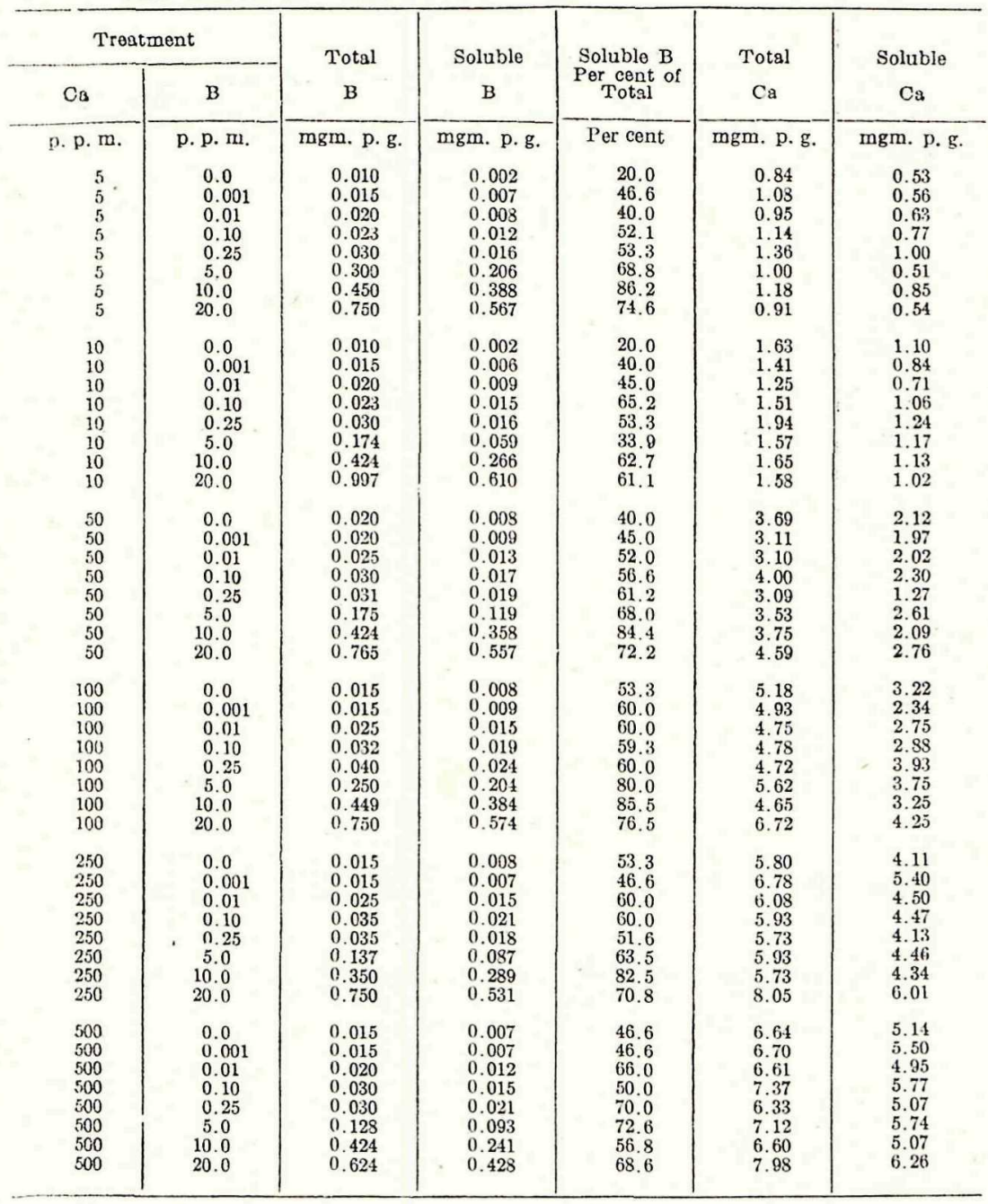

nutrient level of boron (20.0 p.p.m.) were less severe at the highest calcium level (500.0 p.p.m.) than at lower calcium levels. These differences in severity of boron toxicity symptoms were also reflected in the green and dry weight yields of the plants. Parks et al working with tomatoes obtained reduced green and dry weights of plants receiving toxic quantities of boron (31). 


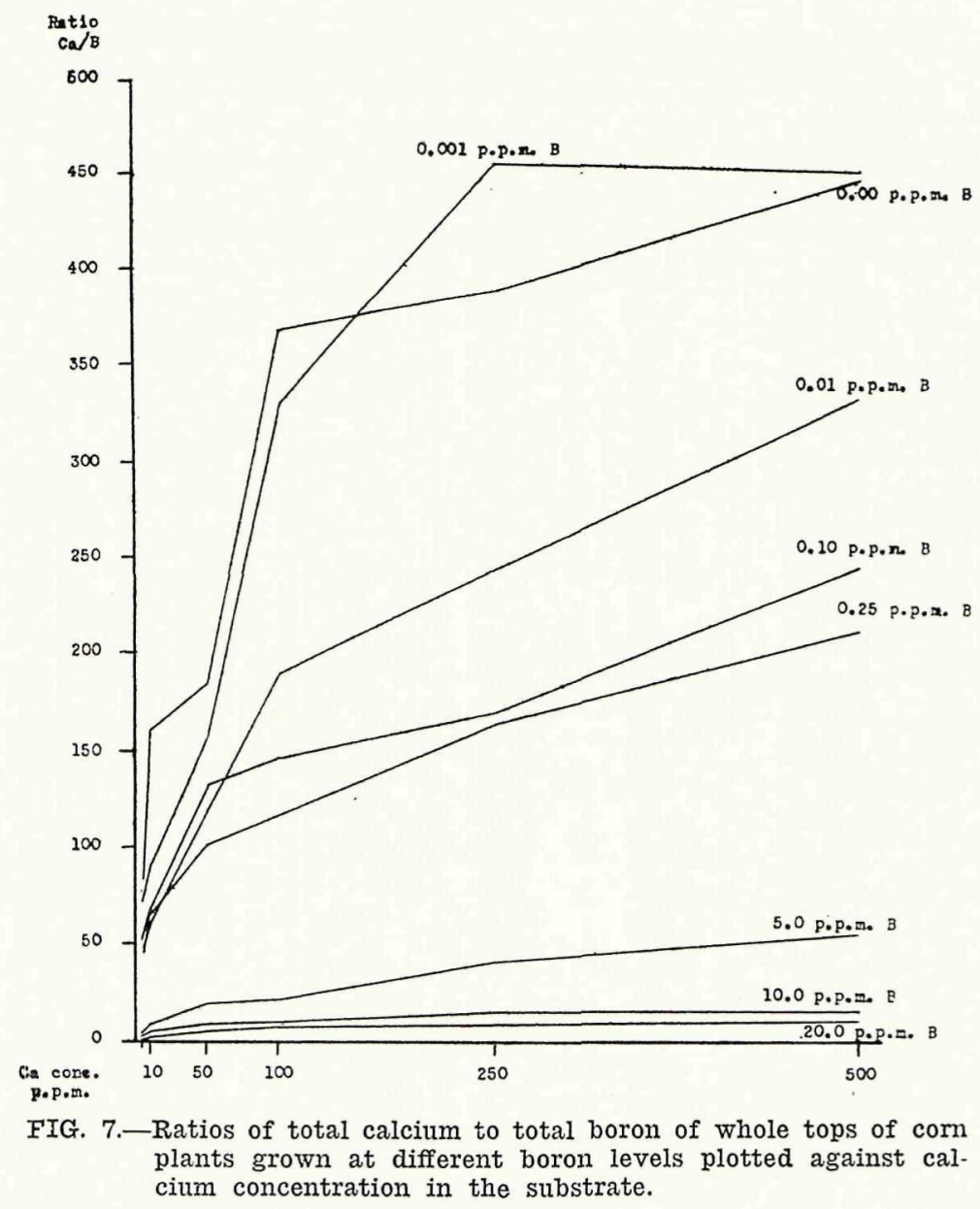

The experimental results also show that, in general, at each nutrient level of calcium a relatively higher percentage of the total boron remains soluble in the corn plant at the three highest boron levels than at the lower boron concentrations. This is similar to results obtained by Marsh with corn in which the lowest and highest percentage of soluble boron occurred at deficient and toxic boron substrate levels respectively (18).

Within any given calcium level the tissue contents of soluble boron were smaller in the plants grown at the two lowest boron levels than at the higher boron levels (table 2). Plants containing the lowest soluble boron at any given calcium level showed evidence of typical boron deficiency symptoms. This suggests that in this ex- 
TABLE No. 3

RATIOS OF DRY WEIGHT TISSUE CONTENTS OF TOTAL CALCIUM TO TOTAL BORON OF WHOLE TOPS OF CORN PLANTS OF SERIES I

\begin{tabular}{|c|c|c|c|c|c|}
\hline \multicolumn{2}{|c|}{ Treatment } & \multirow{2}{*}{$\frac{\text { Total } \mathrm{Ca}}{\text { Total }} \frac{-}{\mathrm{B}}$} & \multicolumn{2}{|c|}{ Treatment } & \multirow{2}{*}{$\frac{\text { Total } \mathrm{Ca}}{\text { Total B }}$} \\
\hline $\mathrm{Ca}$ & $\mathrm{B}$ & & $\mathrm{Cs}$ & B & \\
\hline $\begin{array}{c}\text { p. p. } \mathrm{m} \text {. } \\
5 \\
5 \\
5 \\
5 \\
5 \\
5 \\
5 \\
5 \\
5\end{array}$ & $\begin{array}{l}\text { p. p. m. } \\
\\
0.0 \\
0.001 \\
0.01 \\
0.10 \\
0.25 \\
5.0 \\
10.0 \\
20.0\end{array}$ & $\begin{array}{r}81 \\
72 \\
49 \\
51 \\
45 \\
3 \\
25 \\
1\end{array}$ & $\begin{array}{l}\text { p. p.m. } \\
\left.10^{\prime}\right) \\
100 \\
100 \\
100 \\
100 \\
10^{\prime} \\
100 \\
100\end{array}$ & $\begin{array}{l}\text { p. p.m. } \\
0.0 \\
0.001 \\
0.01 \\
0.10 \\
0.25 \\
5.0 \\
10.0 \\
20.0\end{array}$ & $\begin{array}{r}368 \\
331 \\
191 \\
148 \\
118 \\
22 \\
10 \\
9\end{array}$ \\
\hline $\begin{array}{l}10 \\
10 \\
10 \\
10 \\
10 \\
10 \\
10 \\
10\end{array}$ & $\begin{array}{l}0.0 \\
0.001 \\
0.01 \\
0.10 \\
0.25 \\
5.0 \\
10.0 \\
20.0\end{array}$ & $\begin{array}{c}163 \\
92 \\
63 \\
67 \\
63 \\
9 \\
4 \\
1.6\end{array}$ & $\begin{array}{l}250 \\
250 \\
250 \\
250 \\
250 \\
250 \\
250 \\
250\end{array}$ & $\begin{array}{l}0.0 \\
0.001 \\
0.01 \\
0.10 \\
0.25 \\
5.0 \\
10.0 \\
20.0\end{array}$ & $\begin{array}{r}389 \\
455 \\
244 \\
170 \\
161 \\
43 \\
16 \\
11\end{array}$ \\
\hline $\begin{array}{l}50 \\
50 \\
.50 \\
.50 \\
50 \\
50 \\
50 \\
50\end{array}$ & $\begin{array}{l}0.0 \\
0.001 \\
0.01 \\
0.10 \\
0.25 \\
5.0 \\
10.0 \\
20.0\end{array}$ & $\begin{array}{r}185 \\
156 \\
120 \\
133 \\
103 \\
20 \\
9 \\
6\end{array}$ & $\begin{array}{l}500 \\
500 \\
500 \\
500 \\
500 \\
500 \\
500 \\
500\end{array}$ & $\begin{array}{l}0.0 \\
0.001 \\
0.01 \\
0.10 \\
0.25 \\
5.0 \\
10.0 \\
20.0\end{array}$ & $\begin{array}{r}446 \\
449 \\
323 \\
246 \\
217 \\
56 \\
16 \\
13\end{array}$ \\
\hline
\end{tabular}

periment a constant nutrient supply of boron ranging from 0.01 to 0.25 p.p.m. was required to allow corn plants to grow normally.

From the results with regard to total and soluble calcium presented in table 2, it is evident that total calcium content of the tissue is mainly determined by the calcium concentration in the substrate and is largely independent of the nutrient concentration of boron. At each of the three highest levels of calcium, plants grown with the highest boron treatment had a considerably higher total and soluble calcium content than plants grown with the other boron treatments. These differences appear large enough to have some significance but their determinative factors are not clear.

From the analytical data relating to calcium and boron contents of the plant, the ratios of total calcium to total boron for the plants grown at the different calcium and boron levels have been calculated and presented in table 3 . In figure 7 are presented the same $\mathrm{Ca} / \mathrm{B}$ ratios plotted against calcium concentrations of the substrate. It is evident from the ratios of table 3 that the tissue of boron deficient plants receiving nutrient treatments of 0.0 and 0.001 p.p.m. boron had the highest $\mathrm{Ca} / \mathrm{B}$ ratios at any given nutrient level of calcium while the $\mathrm{Ca} / \mathrm{B}$ ratios of the tissues of boron-toxic plants were the lowest. Tissues of normal plants receiving intermediate amounts of 
boron had intermediate ratios. It appears from the results that the quantitative relationship between calcium and boron in the tissues greatly influences the metabolic activities of the corn plant. The qualitative observations made on the plants (figure 3 and 4) which exhibited symptoms of boron toxicity seem to be definitely associated with the calcium and boron contents of these plants. At 500.0 p.p.m. calcium and 20.0 p.p.m. boron, the boron toxicity symptons were considerably less severe than those of plants grown with the same nutrient level of boron but at lower calcium levels. They also had the highest $\mathrm{Ca} / \mathrm{B}$ ratio, 13 to 1 , while the plants grown at 5.0 p.p.m. calcium and 20.0 p.p.m. boron had a $\mathrm{Ca} / \mathrm{B}$ ratio of only 1 to 1 (table 3.). Although the proportion of calcium to boron in the plants in the first case mentioned above (500.0 p.p.m., 20.0 p.p.m. boron) was probably not the optimum for normal plant metabolism, nevertheless it seemed to be associated in some way with less severe boron toxicity than was evident in the plants grown at the highest boron level at the lowest calcium concentration. These were the plants that had a very low $\mathrm{Ca} / \mathrm{B}$ ratio (figure 3 ). It can also be seen from table 3 that as the boron increased at a given calcium level the $\mathrm{Ca} / \mathrm{B}$ ratio decreased.

\section{Results of Chemical Analyses of Tissue Fractions of Corn Plant Tops}

The results of quantitative tests for total boron and total calcium of the tissue fractions of plants grown at low and high boron levels

TABLE NO. 4

TOTAL BORON AND TOTAL CALCIUM OF TOP LEAVES, MIDDLE STEM, AND LOWER STEM OF CORN PLANTS OF SERIES I EXPRESSED AS MILLIGRAMS PER GRAM DRY TISSUE

\begin{tabular}{c|c|c|c|c|c|c|c}
\multicolumn{2}{c|}{ Treatment } & \multicolumn{2}{c|}{ Top Leaves } & \multicolumn{2}{c|}{ Middle Stem } & \multicolumn{2}{c}{ Low Stom } \\
\cline { 5 - 7 } C3 & B & Total B & Total Ca & Total B & Total Ca & Total B & Total Ca \\
\hline p. p. m. & p. p. m. & mgm. p. g. & mgm. p. g. & mgm. p. g. & mgm. p. g. & mgm. p. g. & mgm. p. g \\
5 & 0.001 & 0.025 & 0.63 & 0.020 & 1.43 & 0.020 & 0.65 \\
5 & 5.0 & 0.180 & 0.43 & 0.325 & 0.92 & 0.080 & 0.58 \\
10 & 0.01 & 0.025 & 1.10 & 0.025 & 1.98 & 0.020 & 0.94 \\
10 & 5.0 & 0.175 & 0.89 & 0.275 & 1.76 & 0.080 & 0.82 \\
50 & 0.01 & 0.030 & 2.19 & 0.025 & 5.02 & 0.020 & 2.41 \\
50 & 5.0 & 0.175 & 2.83 & 0.275 & 3.52 & 0.100 & 1.65 \\
100 & 0.10 & 0.035 & 3.04 & 0.035 & 4.97 & 0.030 & 2.89 \\
100 & 5.0 & 0.199 & 2.70 & 0.225 & 5.19 & 0.080 & 3.04 \\
250 & 0.01 & 0.030 & 5.39 & 0.030 & 8.46 & 0.010 & 6.18 \\
250 & 5.0 & 0.325 & 5.16 & 0.250 & 7.31 & 0.070 & 5.94 \\
500 & 0.001 & 0.030 & 4.23 & 0.020 & 6.41 & 0.010 & 6.28 \\
500 & 5.0 & 0.275 & 4.39 & 0.300 & 10.16 & 0.080 & 8.25 \\
\hline
\end{tabular}


(0.001, 0.01, 0.10 and 5.0 p.p.m.) at each of the six calcium concentrations are presented in table 4 . These were the plants which were divided into top leaves, middle and lower stem fractions. As was pointed out before, this preliminary study was carried out to obtain an idea as to the distribution of the total calcium and boron in these three different portions of the corn plant. An analysis of the data shows that in general at the lowest boron level and at each nutrient level of calcium, boron is more or less equally distributed among top leaves, middle stem, and lower stem, with the least amount found in the lower stem tissue. However, at the highest boron level, and at each calcium level, the boron content of the middle stem was greater than that of the top leaves with but one exception, and the lower stems had the least amount of boron at this boron level.

It is also evident from the resilts presented in table 4 that the tissue content of calcium was greater in the middle stem portion of the plant at any given nutrient level of calcium. The amount of calcium found in each tissue was directly related to the calcium concentration in the substrate, with one exception, and was not greatly influenced by the boron concentration of the nutrient solution, with two exceptions. This occurred in the case of plants grown with the culture solution containing both 5.0 p.p.m. boron and 500.0 p.p.m. calcium where the calcium content of the middle and lower stem was considerably more than the calcium content of the respective tissue fractions of plants grown at 500.0 p.p.m. calcium but with only 0.001 p.p.m. boron.

Table 4 shows also that a relatively large amount of calcium accumulated in the lower stem of the plant at any given calcium level. But at the highest calcium levels (250.0, 500.0 p.p.m.) the lower stem had considerably greater tissue content of calcium than the top leaves. Thus it is evident that at these two highest calcium concentrations a large proportion of calcium accumulated in the lower or older part of the plant and was not freely translocated to the upper or younger leaves of the plant.

\section{SERIES II}

\section{METHODS}

Cultural Methods.-The second eorn series was started on April 18, 1946 to study the response of plants under different environmental conditions from those under which the first experiment was conducted. As before, seeds of Rutgers Hybrid No. 2 field corn selected for uniform size and shape were used in this test. Five 
seeds were planted, in each pot, and after germination the best three seedlings were left to receive treatments. During the first week of growth all corn cultures were supplied with the same dilute culture solution used during the first week with Series I. No boron was added during this period in order that the seedlings might utilize the supply of this element in the seed as far as possible before treatments were started. During the second week of growth all cultures received the same nutrient solution except that boron was added at the rate of 0.01 p.p.m. At the end of the second week all cultures were vigorous and appeared healthy in all respects.

The calcium-boron nutrient treatments were started beginning with the third week and were maintained for 30 days. Before applying treatments to plants, the sand in each culture was flushed with distilled water, then flushed again with the nutrient solutions to be used according to the experimental plan. As before, nutrient solutions were applied by the continuous solution renewal methor. The culture solutions used with the different nutrient levels of calcium and of boron as well as the experimental setup were the same as in Series I. The calcium chloride salt used in the culture solutions of this series was purified by recrystallization after it was found by analysis to contain small amounts of boron. At the end of the experimental period of 30 dars, plants were harrested. As hefore, green and dry weights of the tops were obtained and frozen samples of the plants of each culture were prepared for analysis. In addition, one of the three plants from a culture in each of the six different calcium levels and receiving 0.0, 0.25, and 20.0 p.p.m. boron respectively, was divided into four fractions-top leaves, top stems, lower leaves, and lower stems-for determinations of total and soluble boron and calcium of each tissue.

In the above tissue fractions the "top leaves" consisted of the apical meristem and the leaves arising in its immediate proximity and extending above it. The "top stems" consisted of the culm tissue starting downward from the base of the apical meristem and including the uppermost two differentiated internodes without. attached blacles and sheaths. The "lower leaves" consisted of all the leaves of the stem below the level of the apical meristem. The "lower stem" fraction consisted of the nodes and internodes below the base of the "top stems", as defined above.

Chemical Methods.-The same procedure and methods used in the first series were followed for the determination of total and soluble boron and calcium in the tissues of this corn series. Because 
of the lack of sufficient plant material in some of the tissue fractions it was necessary in thrse eases to ignite a 1-gram instead of a 2-gram sample and to make to $50 \mathrm{ml}$. instead of $100 \mathrm{ml}$. volume.

\section{Results}

Character of Plants after Treatments.-The relative intensities of the external symptoms of metabolic disturbance due to deficient and toxic quantities of boron in the nutrient media are represented by the proportion of the shaded areas in the blocks of the diagram of figure 8. If this diagram is compared with figure 1 a striking difference will be noted in the response of the plants to the low and high boron treatments at the various calcium concentrations. Symptoms of boron deficiency appeared first in the plants at the highest nutrient calcium concentrations, 19 days after treatment. At the end of the experimental period all plants at the two lowest boron levels of 0.0 and 0.001 p.p.m. showed boron deficiency symptoms, except those grown at the two lowest calcium levels. The boron deficiency symptoms increased in severity progressively as the calcium concentration of the substrate increased, except that somewhat more intense boron deficiency symptoms were detected at 250.0 p.p.m. calcium than at 500.0 p.p.m. calcium concentration.

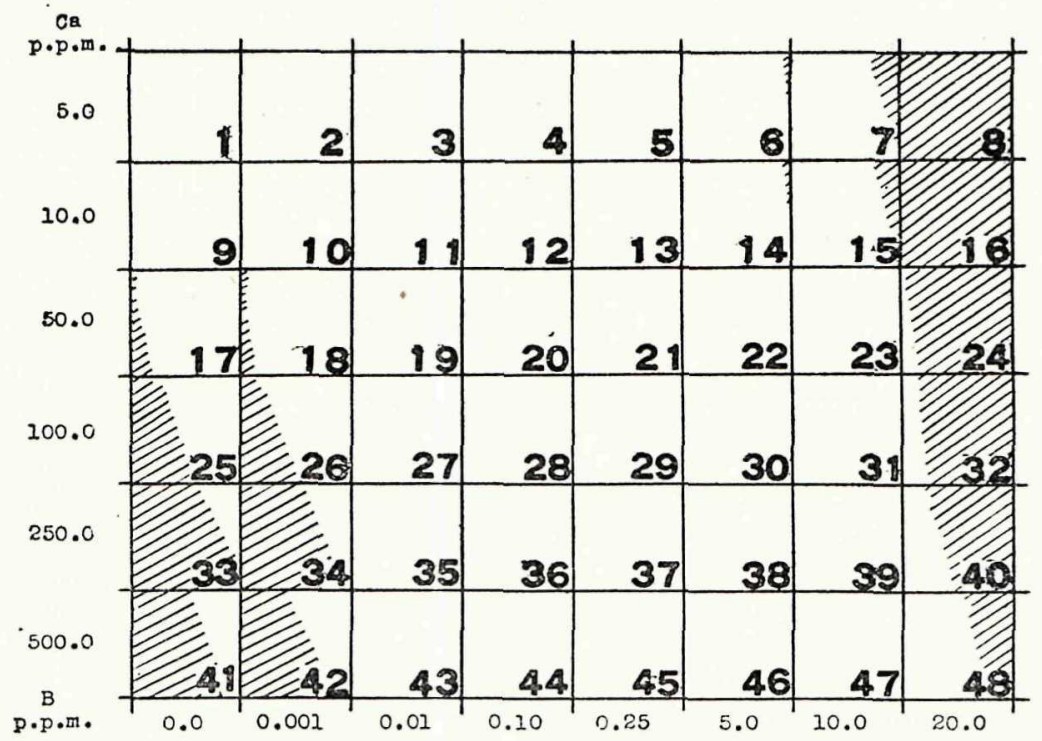

FIG. 8.-Diagram showing calcium and boron treatments and general experimental setup of Series II. Proportionate amounts of shading in the blocks indicate approximate relative severity of boron deficiency symptoms (left) and boron toxicity symptoms (right). 
The growing points of boron deficient plants showed a brownish color as compared to the creamy-white color of growing points of healthy plants. The roots were brown and the root systems were less extensive than those of plants receiving adequate amounts of boron. As before, the boron deficiency symptoms of the roots were most severe at the low calcium levels. This was probably due to combination of both boron and calcium deficiency.

In this series, in contrast to the first series (figures 1,8 ), there was virtually no indication of boron toxicity at 5.0 p.p.m. boron. With the exception of the plants at the two calcium levels of 5.0 and 10.0 p.p.m., where boron toxicity was only slight, the plants at other calcium levels did not show evidence of boron toxicity at 10.0 p.p.m. boron. However, as is evident from figure 8, injury due to boron toxicity occurred at 20.0 p.p.m. boron at all calcium levels but decreased in severity with increasing calcium concentration in the substrate. As in Series I, boron-toxic plants were characterized by a yellow-green color of the top leaves and by brown, dead margins and tips of the older or lower leaves. The roots of these plants were mostly brown and less abundant, especially at the two lowest calcium levels, as compared with the long, silvery-white and healthy roots of the plants receiving boron ranging between 0.01 to 0.25 p.p.m. Roots of plants receiving 5.0 and 10.0 p.p.m. boron showed slight boron injury as evidenced by their light brown color as compared with the silvery-white color of roots of plants supplied with lower concentrations of boron.

In the plants of this series the severity of ealcium defieiency symptoms was considerably more pronounced in plants grown at 5.0 and 10.0 p.p.m. calcium than in the same treatments in Series I planted in the fall season. Plants were most severely injured at the lowest calerum level (5.0 p.p.m.) and were stunted considerably in vegetative growth (30). In some of the plants the young leaves failed to unroll properly and the tips of these cylinders of unrolled leaf tissue were dead or dying. The root systems of these calcium deficient plants were less extensive and were slightly browner than the roots of plants receiving larger amounts of calcium in the substrate. This probably indicates an carly maturity of the tissues.

Results of Chemical Analyses.-The results of quantitative tests for total and soluble boron and calcium are presented in table 5 . An examination of these data clearly demonstrates that the total and soluble boron in the corn plant is largely a direct function of the boron concentration in the substrate and is only slightly in- 
TABLE NO. 5

TOTAL AND SOLUBLE CALCIUM AND BORON IN MILLIGRAMS PER GRAM DRY TISSUE OF WHOLE TOPS OF CORN PLANTS OF SERLES II

\begin{tabular}{|c|c|c|c|c|c|c|}
\hline \multicolumn{2}{|c|}{ Treatment } & \multirow{2}{*}{$\begin{array}{c}\text { Total } \\
\text { B }\end{array}$} & \multirow{2}{*}{$\begin{array}{c}\text { Soluble } \\
\text { B }\end{array}$} & \multirow{2}{*}{$\begin{array}{l}\text { Soluble B } \\
\text { Per cent of } \\
\text { Total }\end{array}$} & \multirow{2}{*}{$\begin{array}{c}\text { Total } \\
\mathrm{Ca}\end{array}$} & \multirow{2}{*}{$\begin{array}{c}\text { Soluble } \\
\qquad \mathrm{Ca}\end{array}$} \\
\hline $\mathrm{Ca}$ & B & & & & & \\
\hline p. p. m. & p. p.m. & mgm. p. g. & mgm. p. g. & Per cent & mgm. p.g. & mgm. p. g. \\
\hline 5 & 0.0 & 0.020 & 0.007 & 30.0 & 0.61 & 0.30 \\
\hline 5 & 0.001 & 0.030 & 0.013 & 43.3 & 0.72 & 0.30 \\
\hline 5 & 0.01 & 0.040 & 0.022 & 55.0 & 0.61 & 0.31 \\
\hline 5 & 0.10 & 0.045 & 0.026 & 57.7 & 0.78 & 0.39 \\
\hline$\stackrel{5}{5}$ & $\begin{array}{l}0.25 \\
5.0\end{array}$ & $\begin{array}{l}0.045 \\
0.175\end{array}$ & $\begin{array}{l}0.025 \\
0.132\end{array}$ & $\begin{array}{l}55.5 \\
75.3\end{array}$ & $\begin{array}{l}0.66 \\
0.63\end{array}$ & 0.25 \\
\hline 5 & 10.0 & 0.424 & 0.358 & 84.7 & 0.69 & 0.22 \\
\hline 5 & 20.0 & 0.624 & 0.529 & 84.7 & 0.54 & 0.18 \\
\hline 10 & 0.0 & 0.020 & 0.006 & 20.0 & 0.97 & 0.55 \\
\hline 10 & 0.001 & 0.025 & 0.013 & 52.0 & 0.81 & 0.51 \\
\hline 10 & 0.01 & 0.030 & 0.015 & 53.3 & 0.86 & 0.53 \\
\hline 10 & 0.10 & 0.035 & 0.023 & 65.7 & 0.92 & 0.58 \\
\hline 10 & 0.25 & 0.035 & 0.025 & 71.4 & 0.92 & 0.42 \\
\hline 10 & 5.0 & 0.175 & 0.147 & 84.0 & 0.78 & 0.39 \\
\hline 10 & 10.0 & 0.325 & 0.265 & 81.5 & 0.88 & 0.54 \\
\hline 10 & 20.0 & 0.625 & 0.536 & 85.7 & 0.77 & 0.45 \\
\hline 50 & 0.0 & 0.025 & 0.011 & 44.4 & 2.87 & 1.96 \\
\hline 50 & 0.001 & 0.025 & 0.013 & 52.0 & 2.33 & 1. 62 \\
\hline 50 & 0.01 & 0.030 & 0.017 & 56.6 & 2.64 & 1.72 \\
\hline 50 & 0.10 & 0.035 & 0.023 & 65.7 & 2.58 & 1.83 \\
\hline 50 & 0.25 & 0.040 & 0.025 & 62.5 & 2.11 & 1.24 \\
\hline 50 & 5.0 & 0.137 & 0.119 & 86.8 & 2.34 & 1.80 \\
\hline 50 & 10.0 & 0.325 & 0.288 & 88.8 & 2.56 & 1.96 \\
\hline 50 & 20.0 & 0.625 & 0. .526 & 76.4 & 2.36 & 1.31 \\
\hline 100 & 0.0 & 0.020 & 0.009 & 45.0 & 4. 49 & 3.33 \\
\hline 100 & 0.001 & 0.020 & 0.010 & 50.0 & 4.33 & 3.19 \\
\hline 100 & 0.01 & 0.025 & 0.012 & 48.0 & 3.69 & 2.78 \\
\hline 100 & 0.10 & 0.029 & 0.020 & 68.9 & 3.39 & 2.15 \\
\hline 100 & 0.25 & 0.040 & 0.022 & 55.0 & 4.09 & 3.18 \\
\hline 100 & 5.0 & 0.137 & 0.102 & 74.4 & 3.77 & 2.52 \\
\hline 100 & 10.0 & 0.325 & 0.267 & 82.1 & 4.36 & 3.37 \\
\hline 100 & 20.0 & 0.749 & 0.650 & 86.7 & 4.42 & 3.26 \\
\hline 250 & 0.0 & 0.020 & 0.009 & 45.0 & 5.39 & 2.76 \\
\hline 250 & 0.001 & 0.025 & 0.012 & 40.0 & 5.06 & 3.36 \\
\hline 250 & 0.01 & 0.025 & 0.015 & 60.0 & 4.82 & 3.49 \\
\hline 250 & 0.10 & 0.030 & 0.019 & 63.3 & 3.95 & 3.01 \\
\hline 250 & 0.25 & 0.040 & 0.022 & 55.0 & 4.97 & 3.70 \\
\hline 250 & 5.0 & 0.137 & 0.111 & 81.0 & 4. 70 & 3.50 \\
\hline 250 & 10.0 & 0.325 & 0.263 & 80.9 & 5.60 & 4.32 \\
\hline 250 & 20.0 & 0.750 & 0.608 & 81.0 & 5.11 & 3.58 \\
\hline 500 & 0.0 & 0.025 & 0.010 & 40.0 & 5.56 & 4.62 \\
\hline 500 & 0.001 & 0.025 & 0.010 & 40.0 & 5.27 & 3.84 \\
\hline 500 & 0.01 & 0.030 & 0.019 & 63.3 & 5.70 & 3.38 \\
\hline 500 & 0.10 & 0.040 & 0.021 & 52.5 & 6.07 & 3.38 \\
\hline 500 & 0.25 & 0.040 & 0.025 & 62.5 & 5.15 & $4.0 \frac{1}{2}$ \\
\hline 500 & 5.0 & 0.175 & 0.139 & 79.4 & 5.59 & 3.92 \\
\hline 500 & 10.0 & 0.325 & 0.255 & 78.4 & 5.55 & 4.13 \\
\hline 500 & 20.0 & 0.625 & 0.447 & 71.5 & 9.25 & 5.84 \\
\hline
\end{tabular}

fluenced by the calcium levcl. It is also evident from table 5 that, as was found in Series I, the soluble boron within the plant was somewhat less at the highest calcium level (500.0 p.p.m.) than at all of the lower nutrient levels of calcium. As in the first series, the data also show that in most cases a relatively higher percentage of the total boron remains soluble in the corn plant at the high boron levels than at lower nutrient levels of boron. However, the data fail to explain the qualitative observations made earlier with 
TABLE NO. 6

RATIOS OF DRY WEIGHT TISSUE CONTENTS OF TOTAL CALCIUM TO TOTAI BORON OF WHOLE TOPS OF CORN PLANTS OF SERIES II

\begin{tabular}{|c|c|c|c|c|c|}
\hline \multicolumn{2}{|c|}{ Treatment } & \multirow{2}{*}{$\frac{\text { Total } \mathrm{Ca}}{\text { Total } \mathrm{B}}$} & \multicolumn{2}{|c|}{ Treatment } & \multirow{2}{*}{$\frac{\text { Total } \mathrm{Ca}}{\text { Total B }}$} \\
\hline $\mathrm{Ca}$ & B & & $\mathrm{Ca}$ & B & \\
\hline $\begin{array}{c}\text { p. p. m. } \\
5 \\
5 \\
5 \\
5 \\
5 \\
5 \\
5 \\
5\end{array}$ & $\begin{array}{l}\text { p. p. m. } \\
\\
0.0 \\
0.001 \\
0.01 \\
0.10 \\
0.25 \\
5.0 \\
10.0 \\
20.0\end{array}$ & $\begin{array}{l}31 \\
24 \\
15 \\
17 \\
15 \\
3 \\
2 \\
0.9\end{array}$ & $\begin{array}{l}\text { p. p. m. } \\
100 \\
100 \\
100 \\
109 \\
103 \\
103 \\
100 \\
100\end{array}$ & $\begin{array}{l}\text { p. p. m. } \\
\\
0.0 \\
0.001 \\
0.01 \\
0.10 \\
0.25 \\
5.0 \\
10.0 \\
20.0\end{array}$ & $\begin{array}{r}220 \\
.218 \\
148 \\
119 \\
103 \\
27 \\
13 \\
6\end{array}$ \\
\hline $\begin{array}{l}10 \\
10 \\
10 \\
10 \\
10 \\
10 \\
10 \\
10\end{array}$ & $\begin{array}{l}0.0 \\
0.001 \\
0.01 \\
0.10 \\
0.25 \\
5.0 \\
10.0 \\
20.0\end{array}$ & $\begin{array}{r}49 \\
33 \\
29 \\
26 \\
26 \\
4 \\
3 \\
1\end{array}$ & $\begin{array}{l}250 \\
250 \\
250 \\
250 \\
250 \\
250 \\
250 \\
250\end{array}$ & $\begin{array}{l}0.0 \\
0.001 \\
0.01 \\
0.10 \\
0.25 \\
5.0 \\
10.0 \\
20.0\end{array}$ & $\begin{array}{r}271 \\
203 \\
194 \\
132 \\
125 \\
34 \\
17 \\
7\end{array}$ \\
\hline $\begin{array}{l}50 \\
50 \\
50 \\
50 \\
50 \\
50 \\
50 \\
50\end{array}$ & $\begin{array}{l}0.0 \\
0.001 \\
0.01 \\
0.10 \\
0.25 \\
5.0 \\
10.0 \\
20.0\end{array}$ & $\begin{array}{r}115 \\
94 \\
88 \\
74 \\
53 \\
17 \\
8 \\
6\end{array}$ & $\begin{array}{l}500 \\
500 \\
500 \\
500 \\
500 \\
500 \\
500 \\
500\end{array}$ & $\begin{array}{l}0.0 \\
0.001 \\
0.01 \\
0.10 \\
0.25 \\
5.0 \\
10.0 \\
20.0\end{array}$ & $\begin{array}{r}223 \\
212 \\
193 \\
152 \\
129 \\
32 \\
17 \\
15\end{array}$ \\
\hline
\end{tabular}

regard to boron deficiency, that is, that this injury is intensified with increasing concentrations of calcium in the substrate, nor does it satisfactorily explain why boron toxicity decreased with increasing concentrations of calcium in the substrate. In tomato plants $(4,37)$, the qualitative observations are in agreement with the quantitative data with regard to boron deficient and boron toxic plants. An explanation for this lack of agreement in the corn plant will be given later when the quantitative relationship between calcium and boron in the plant is considered, together with the analytical data with respect to total and soluble boron of the fractionated portions of the plant.

From the results presented with regard to total and soluble calcium of the plant, it is evident that the same trend follows as with the results obtained for the first series, that is, that the calcium content in the tissues is largely determined by the calcium concentration of the growth medium and is not greatly influenced by boron, with one principal exception, namely, in the case of plants grown at 500.0 p.p.m. calcium and 20.0 p.p.m. boron where total and soluble calcium content was much higher as compared with that of plants grown at the same calcium level but different boron concentrations. With the exception mentioned abcve, similar results were obtained 
TABLE NO. 7

TOTAL AND SOLUBLE BORON AND CALCIUM IN MILLIGRAMS PER GRAM DRY TISSUE OF TOP LEAVES OF CORN PLAN'TS OF SERIES II

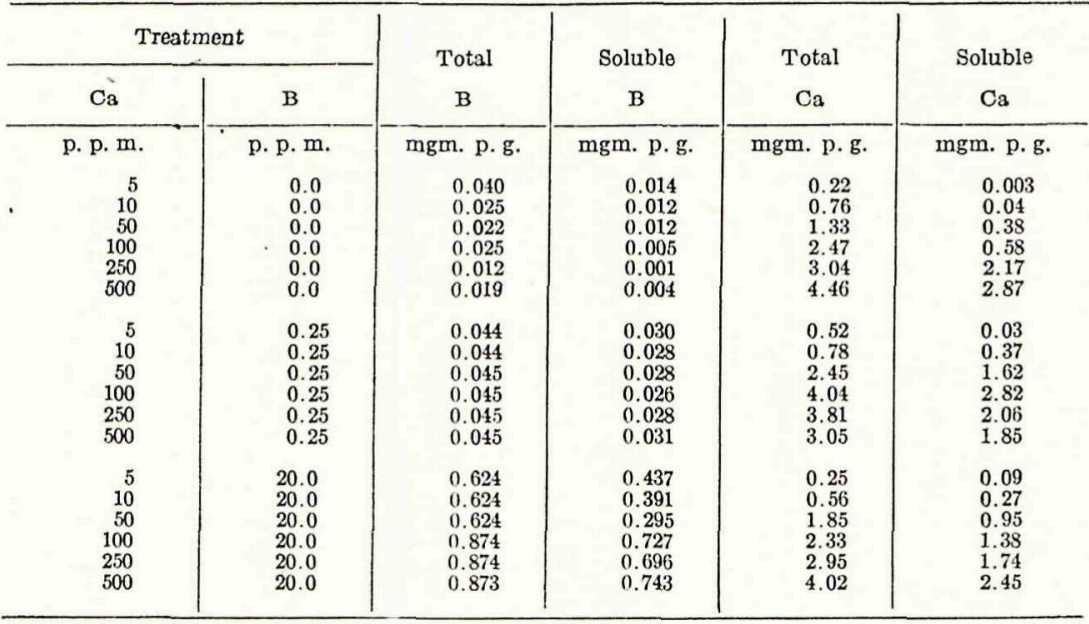

by Warington working with Vicia faba (47), Reeve (36), Brennan (4) working with tomato, and Reeve and Shive (37) working with both corn and tomato plants.

Again the ratios of total calcium to total boron in the plants were calculated and are presented in table 6 . As in Series I, somewhat similar differences in ratios were obtained. It is evident from table 6 that, in general, at a given boron level as the calcium concentration in the substrate increase, the ratio of $\mathrm{Ca} / \mathrm{B}$ increases also, while at a given calcium level as the boron in the substrate increases, the ratio decreases. Plants showing boron deficient symptoms had rather high $\mathrm{C}: \mathrm{a} / \mathrm{B}$ ratios especially at the higher calcium concentrations in the substrate, whereas plants with relatively intense boron-toxic symptoms had a very low ratio at the low calcium concentrations as compared with the intermediate ratios of healthy plants. As with the first corn series, the ratios presented indicate that a certain balance must exist between the calcium and boron content of the corn tissue to fulfill the requirements of healthy individuals. The fact that boron deficient and boron toxic plants had a high and low $\mathrm{Ca} / \mathrm{I}$, ratio, respectively, points to the importance of the relationship between these two elements within the plant. The data of table 6 show that at the highest boron level (20.0 p.p.m.) as the calcium concentration of the substrate was increased the $\mathrm{Ca} / \mathrm{B}$ ratio increaserl, as was to be expected, and is considerably higher at the last four calcium levels $(50.0,100.0,250.0,500.0$ p.p.m. calcium) than at the first two calcium levels, respectively, (5.0, 
TABLE No. 8

TOTAL AND SOLUBLE BORON AND CALCIUM IN MILLIGRAMS PER GRAM DRY TISSUE OF LOW LEAVES OF CORN PLANTS OF SERIES II

\begin{tabular}{|c|c|c|c|c|c|}
\hline \multicolumn{2}{|c|}{ Treatment } & \multirow{2}{*}{$\begin{array}{c}\text { Total } \\
\text { B }\end{array}$} & \multirow{2}{*}{$\begin{array}{c}\text { Soluble } \\
\text { B }\end{array}$} & \multirow{2}{*}{$\begin{array}{c}\text { Total } \\
\mathrm{Ca}\end{array}$} & \multirow{2}{*}{$\begin{array}{c}\text { Soluble } \\
\qquad \mathrm{Ca}\end{array}$} \\
\hline $\mathrm{Ca}$ & B & & & & \\
\hline p. p. m. & p. p.m. & mgm. p. g. & mgm. p. g. & mgm. p.g. & mgm. p. g. \\
\hline $\begin{array}{r}5 \\
10 \\
50 \\
100 \\
250 \\
500\end{array}$ & $\begin{array}{l}0.0 \\
0.0 \\
0.0 \\
0.0 \\
0.0 \\
0.0\end{array}$ & $\begin{array}{l}0.030 \\
0.025 \\
0.025 \\
0.025 \\
0.022 \\
0.040\end{array}$ & $\begin{array}{l}.005 \\
.015 \\
.014 \\
.005 \\
.012 \\
.023\end{array}$ & $\begin{array}{r}1.16 \\
1.43 \\
3.80 \\
4.83 \\
7.61 \\
9.13\end{array}$ & $\begin{array}{l}0.48 \\
0.62 \\
1.63 \\
3.04 \\
5.24 \\
6.88\end{array}$ \\
\hline $\begin{array}{r}5 \\
10 \\
50 \\
100 \\
250 \\
500\end{array}$ & $\begin{array}{l}0.25 \\
0.25 \\
0.25 \\
0.25 \\
0.25 \\
0.25\end{array}$ & $\begin{array}{l}0.056 \\
0.044 \\
0.045 \\
0.045 \\
0.045 \\
0.045\end{array}$ & $\begin{array}{l}.037 \\
.025 \\
.025 \\
.027 \\
.028 \\
.028\end{array}$ & $\begin{array}{l}0.96 \\
1.35 \\
4.59 \\
5.48 \\
8.72 \\
7.77\end{array}$ & $\begin{array}{l}0.61 \\
0.55 \\
3.41 \\
4.03 \\
6.25 \\
5.81\end{array}$ \\
\hline $\begin{array}{r}5 \\
10 \\
50 \\
100 \\
250 \\
500\end{array}$ & $\begin{array}{l}20.0 \\
20.0 \\
20.0 \\
20.0 \\
20.0 \\
20.0\end{array}$ & $\begin{array}{l}1.750 \\
0.874 \\
0.874 \\
1.130 \\
1.500 \\
1.500\end{array}$ & $\begin{array}{r}1.585 \\
.737 \\
.455 \\
.970 \\
1.342 \\
1.335\end{array}$ & $\begin{array}{r}0.91 \\
0.88 \\
4.01 \\
4.67 \\
7.52 \\
10.33\end{array}$ & $\begin{array}{l}0.52 \\
9.49 \\
2.46 \\
3.32 \\
5.73 \\
8.12\end{array}$ \\
\hline
\end{tabular}

10.0 p.p.m. calcium). It was at these last four calcium concentrations that the plants showed a decrease in the intensity of injury due to boron toxicity, as can be observed in figure 8 . The less toxic boron plants had a $\mathrm{Ca} / \mathrm{B}$ ratio of 7 and 15 respectively as compared with ratios of 0.9 and 1 respectively of those plants showing much more boron toxicity. Thus it is apparent that there seems to exist a direct association between the appearance of boron deficiency and toxicity symptoms in the corn plant and the quantitative relationships of calcium and boron within the plant.

Results of Chemical Analyses of Tissue Fractions.-The analytical results of quantitative tests for total and soluble boron and total and soluble calcium of the tissues of the fractionated plants are presented in tables $7,8,9$, and 10 . The results obtained bring out several interesting points with regard to total and soluble boron content of the various tissues at the different boron levels. The tables show that, in general, at the lowest boron concentration of the substrate there was a greater accumulation of total and soluble boron in the older tissues of the plant (top stems, low stems, and low leaves) than in the top leaves and these differences were particularly marked at the highest nutrient levels of calcium. At the lowest nutrient level of boron the soluble boron contents of the top leaves at the three highest calcium levels (100.0, 250.0, and 500.0 p.p.m.) are relatively low as compared with the values at the three lower calcium levels. These data are in agreement with the qualita- 
TABLE No. 9

TOTAL AND SOLUBLE BOION AND CALCIUM IN MILLIORAMS PER GRAM DRY 'TISSUE OF TOP STEMS OF CORN OF SERIES II

\begin{tabular}{|c|c|c|c|c|c|}
\hline \multicolumn{2}{|c|}{ Treatment } & \multirow{2}{*}{$\begin{array}{c}\text { Total } \\
\text { B }\end{array}$} & \multirow{2}{*}{$\begin{array}{c}\text { Soluble } \\
\text { B }\end{array}$} & \multirow{2}{*}{$\begin{array}{c}\text { Total } \\
\mathrm{Ca}\end{array}$} & \multirow{2}{*}{$\begin{array}{c}\text { Soluble } \\
\mathrm{Ca}\end{array}$} \\
\hline $\mathrm{Cs}$ & B & & & & \\
\hline p. p. m. & p. p. m. & mgm. p. g. & mgm. p. g. & mgm. p. g. & mgm. p. g. \\
\hline $\begin{array}{r}5 \\
10 \\
50 \\
100 \\
250 \\
500\end{array}$ & $\begin{array}{l}0.0 \\
0.0 \\
0.0 \\
0.0 \\
0.0 \\
0.0\end{array}$ & $\begin{array}{l}\ldots .030 \\
0.030 \\
0.030 \\
0.040 \\
0.050\end{array}$ & $\begin{array}{l}\ldots .011 \\
0.013 \\
0.009 \\
0.017 \\
0.016\end{array}$ & $\begin{array}{l}0.75 \\
1.42 \\
1.78 \\
2.93 \\
3.51\end{array}$ & $\begin{array}{r}\ldots .41 \\
0.99 \\
1.13 \\
1.88 \\
2.59\end{array}$ \\
\hline $\begin{array}{r}5 \\
10 \\
50 \\
100 \\
250 \\
500\end{array}$ & $\begin{array}{l}0.25 \\
0.25 \\
0.25 \\
0.25 \\
0.25 \\
0.25\end{array}$ & $\begin{array}{l}0.050 \\
0.045 \\
0.030 \\
0.040 \\
0.040 \\
0.050\end{array}$ & $\begin{array}{l}0.023 \\
0.027 \\
0.012 \\
0.013 \\
0.015 \\
0.019\end{array}$ & $\begin{array}{l}0.44 \\
0.50 \\
1.34 \\
2.00 \\
2.45 \\
4.55\end{array}$ & $\begin{array}{l}0.17 \\
0.26 \\
0.85 \\
1.36 \\
1.68 \\
1.64\end{array}$ \\
\hline $\begin{array}{r}5 \\
10 \\
50 \\
100 \\
250 \\
500\end{array}$ & $\begin{array}{l}20.0 \\
20.0 \\
20.0 \\
20.0 \\
20.0 \\
20.0\end{array}$ & $\begin{array}{l}0.125 \\
0.350 \\
0.299 \\
0.225 \\
0.274 \\
0.225\end{array}$ & $\begin{array}{l}0.087 \\
0.307 \\
C .261 \\
0.202 \\
0.218 \\
0.178\end{array}$ & $\begin{array}{l}0.26 \\
0.56 \\
1.89 \\
2.73 \\
7.01 \\
6.44\end{array}$ & $\begin{array}{l}0.01 \\
0.11 \\
1.32 \\
1.96 \\
5.50 \\
4.99\end{array}$ \\
\hline
\end{tabular}

tive observations made at the time of harvest, when it was noted that the boron-deficiency symptoms of the top leaves of the corn plant were most severe at the three highest calcium levels. However, it should be mentioned that the boron deficient injury was more pronounced in the plants supplied with 250.0 p.p.m. calcium than at either of the other two highest calcium levels. Thus, it is evident, that symptoms of boron deficiency are associated with the presence of small amounts of boron in the top portions of boron deficient plants as compared with plants receiving adequate amounts of boron (9). It appears from the results presented that at low boron concentration, a large proportion of boron accumulates in the older tissues of the plants and is not freely translocated to the top leaves where synthetic activity is highest. The fact that a large part of the total and soluble boron in plants to which boron was not intentionally supplied accumulated in the lower or older tissues instead of in the top leaves was probably responsible for the lack of agreement between the qualitative observations of boron deficient plants made at the time of harvest and quantitative results of the same plants when a composite sample of the whole top was analyzed for total and soluble boron. Unquestionably the low total and soluble boron content of the top leaves was masked by the presence of tissues containing high total and soluble boron (top stems, low leaves, and low stems) in the composite sample and, therefore, the qualitative observations of the boron deficient plants were not confirmed by quantitative analysis of whole tops. This indicates that the values 
TABLE No. 10

TOTAL AND SOLUBLE BORON AND CALCIUM IN MILLIGRAMS PER GRAM DRY TISSUE OF LOW STEMS OF CORN PLANTS OF SERIES II

\begin{tabular}{|c|c|c|c|c|c|}
\hline \multicolumn{2}{|c|}{ Treatment } & \multirow{2}{*}{$\begin{array}{c}\text { Total } \\
\text { B }\end{array}$} & \multirow{2}{*}{$\begin{array}{c}\text { Soluble } \\
\text { B }\end{array}$} & \multirow{2}{*}{$\begin{array}{c}\text { Total } \\
\mathrm{Ca}\end{array}$} & \multirow{2}{*}{$\begin{array}{c}\text { Soluble } \\
\mathrm{Ca}\end{array}$} \\
\hline $\mathrm{Ca}$ & B & & & & \\
\hline p. p. m. & p. p. m. & mgm. p. g. & mgm. p. g. & mgm. p. g. & mgm. p. g. \\
\hline $\begin{array}{r}5 \\
10 \\
50 \\
100 \\
250 \\
500\end{array}$ & $\begin{array}{l}0.0 \\
0.0 \\
0.0 \\
0.0 \\
0.0 \\
0.0\end{array}$ & $\begin{array}{l}0.020 \\
0.045 \\
0.045 \\
0.020 \\
0.030 \\
0.040\end{array}$ & $\begin{array}{l}0.004 \\
0.017 \\
0.030 \\
0.008 \\
0.013 \\
0.012\end{array}$ & $\begin{array}{l}0.29 \\
0.54 \\
1.26 \\
3.36 \\
4.05 \\
6.86\end{array}$ & $\begin{array}{l}0.13 \\
0.30 \\
0.89 \\
2.86 \\
3.22 \\
5.58\end{array}$ \\
\hline $\begin{array}{r}5 \\
10 \\
50 \\
100 \\
250 \\
500\end{array}$ & $\begin{array}{l}0.25 \\
0.25 \\
0.25 \\
0.25 \\
0.25 \\
0.25\end{array}$ & $\begin{array}{l}0.022 \\
0.022 \\
0.034 \\
0.045 \\
0.045 \\
0.040\end{array}$ & $\begin{array}{l}0.008 \\
0.008 \\
0.014 \\
0.024 \\
0.020 \\
0.016\end{array}$ & $\begin{array}{l}0.28 \\
0.35 \\
1.56 \\
2.88 \\
3.46 \\
5.54\end{array}$ & $\begin{array}{l}0.15 \\
0.21 \\
1.19 \\
2.29 \\
2.66 \\
4.20\end{array}$ \\
\hline $\begin{array}{r}5 \\
10 \\
50 \\
100 \\
250 \\
500\end{array}$ & $\begin{array}{l}20.0 \\
20.0 \\
20.0 \\
20.0 \\
20.0 \\
20.0\end{array}$ & $\begin{array}{l}0.175 \\
0.350 \\
0.349 \\
0.274 \\
0.349 \\
0.350\end{array}$ & $\begin{array}{l}0.161 \\
0.313 \\
0.309 \\
0.246 \\
0.304 \\
0.302\end{array}$ & $\begin{array}{r}0.29 \\
0.34 \\
2.01 \\
2.41 \\
6.99 \\
13.33\end{array}$ & $\begin{array}{r}0.03 \\
0.15 \\
1.46 \\
1.92 \\
5.97 \\
11.29\end{array}$ \\
\hline
\end{tabular}

of total and soluble boron contents of boron deficient plants as a whole do not provide reliable criteria of the concentration present in any given tissue.

The plants of the cultures supplied with 0.25 p.p.m. boron showed a much more equal distribution of this element throughout the various tissues than plants supplied with no boron or with very high nutrient levels of this element. At the nutrient level of 0.25 p.p.m. boron there was relatively little variation in the total boron contents of any given tissue fraction of plants grown with different calcium levels. At the same nutrient level of boron (0.25 p.p.m.) the soluble boron was higher in the top leaves and lower leaves than in the top and lower stems of the plants at any given calcium level, except in one case. This might be expected, since the leaves are more active than the stems in metabolic processes in which boron must take part.

The analytical data for total and soluble boron of all the cultures supplied with 20.0 p.p.m. boron show that the distribution of boron in the plant followed a definite course (19). The greatest amount of total and soluble boron accumulated in the lower leaves, while a considerably lesser amount was found in the top leaves. Low stems had a higher boron content than top stems. The qualitative observations made in regard to boron toxicity symptoms of plants grown at the highest boron level are in agreement with the quantitative data 
TABLE No. 11

RATIOS OF DRY WEIGHT TISSUE CONTENTS OF TOTAL CALCIUM TO TOTAL BORON IN THE VARIOUS FRACTIONS OF THE CORN PLANTS OF SERIES II

\begin{tabular}{|c|c|c|c|c|c|}
\hline \multicolumn{2}{|c|}{ Treatment } & Top Leaves & Low Leaves & Top Stems & Low Stems \\
\hline $\mathrm{Ca}$ & B & Total B & Total B & Total B & Total B \\
\hline p. p. m. & p. p. m. & & & & \\
\hline $\begin{array}{c}5 \\
10 \\
50 \\
100 \\
250 \\
500\end{array}$ & $\begin{array}{l}0.0 \\
0.0 \\
0.0 \\
0.0 \\
0.0 \\
0.0\end{array}$ & $\begin{array}{r}5 \\
31 \\
59 \\
99 \\
245 \\
221\end{array}$ & $\begin{array}{r}38 \\
57 \\
153 \\
194 \\
340 \\
229\end{array}$ & $\begin{array}{l}25 \\
47 \\
60 \\
73 \\
70\end{array}$ & $\begin{array}{r}15 \\
12 \\
28 \\
169 \\
135 \\
172\end{array}$ \\
\hline $\begin{array}{r}5 \\
10 \\
50 \\
100 \\
250 \\
500\end{array}$ & $\begin{array}{l}0.25 \\
0.25 \\
0.25 \\
0.25 \\
0.25 \\
0.25\end{array}$ & $\begin{array}{l}12 \\
18 \\
55 \\
90 \\
85 \\
68\end{array}$ & $\begin{array}{r}17 \\
31 \\
102 \\
123 \\
194 \\
173\end{array}$ & $\begin{array}{r}9 \\
11 \\
45 \\
50 \\
62 \\
91\end{array}$ & $\begin{array}{r}13 \\
16 \\
46 \\
65 \\
77 \\
139\end{array}$ \\
\hline $\begin{array}{r}5 \\
10 \\
50 \\
100 \\
250 \\
500\end{array}$ & $\begin{array}{l}20.0 \\
20.0 \\
20.0 \\
20.0 \\
20.0 \\
20.0\end{array}$ & $\begin{array}{l}0.4 \\
0.9 \\
3.0 \\
3.0 \\
3.0 \\
5.0\end{array}$ & $\begin{array}{l}0.5 \\
0.7 \\
5.0 \\
4.0 \\
5.0 \\
7.0\end{array}$ & $\begin{array}{r}2 \\
2 \\
6 \\
12 \\
26 \\
29\end{array}$ & $\begin{array}{r}2 \\
1 \\
6 \\
9 \\
20 \\
38\end{array}$ \\
\hline
\end{tabular}

presented. The higher concentration of boron in the lower leaves paralleled the presence of boron toxic effects as evidenced by the brown and dead margins and tips of the lower leaves of the plants. Similar results were obtained by Eaton (8) and Purvis (34) due to a great accumulation of boron in the lower leaves of the plants.

The data further show that the total and soluble boron content of the various tissues depended largely upon the boron concentration of the substrate. However, in some cases the relative calcium concentration of the substrate modified the accumulation of this element within the plant at a given boron level, the greatest modification occurring at the highest boron level. As a general rule, the leaves were more sensitive to boron changes in the substrate than were either the top or low stems. Parks, Lyons, and Hood (31) reported that as boron supply in the substrate increased, the concentration of boron in the leaves increased significantly.

Calcium Content of Plant Tissues.-The analytical evidence gathered with reference to the calcium content of the various tissues of the corn plant shows that its distribution is regular and definite. The greatest amount of total and soluble calcium was found in the leaves of the plant, the lower leaves having the largest amount of this element (45). In general, the lower stems had a much higher calcium content than the top stems. The fact that much more total 
and soluble ealcium was found in the lower leaves and lower stems suggests that most of it was tied up in this lower portion of the plant and, therefore, was not freely translocated to the younger tissue where meristematic activity is highest. As a result of this condition the severe calcium deficiency symptoms of the cultures grown at 5.0 p.p.m. calcium and less marked deficiency symptoms at 10.0 p.p.m. calcium can be explained. It is interesting to note from table 7 that the top leaves of those plants grown at these two lowest calcium levels without boron contained considerably less soluble calcium than the top leaves of those plants grown at the same calcium levels but having boron in the substrate. The total calcium of the top leaves of the calcium deficient plants (5.0, 10.0 p.p.m. calcium) receiving no boron and 20.0 p.p.m. boron respectively at each of the two lowest calcium levels are comparable. There were only little differences between the total calcium contents of the top leaves of the plants grown at the lowest boron level $(0.0$ p.p.m.) and the

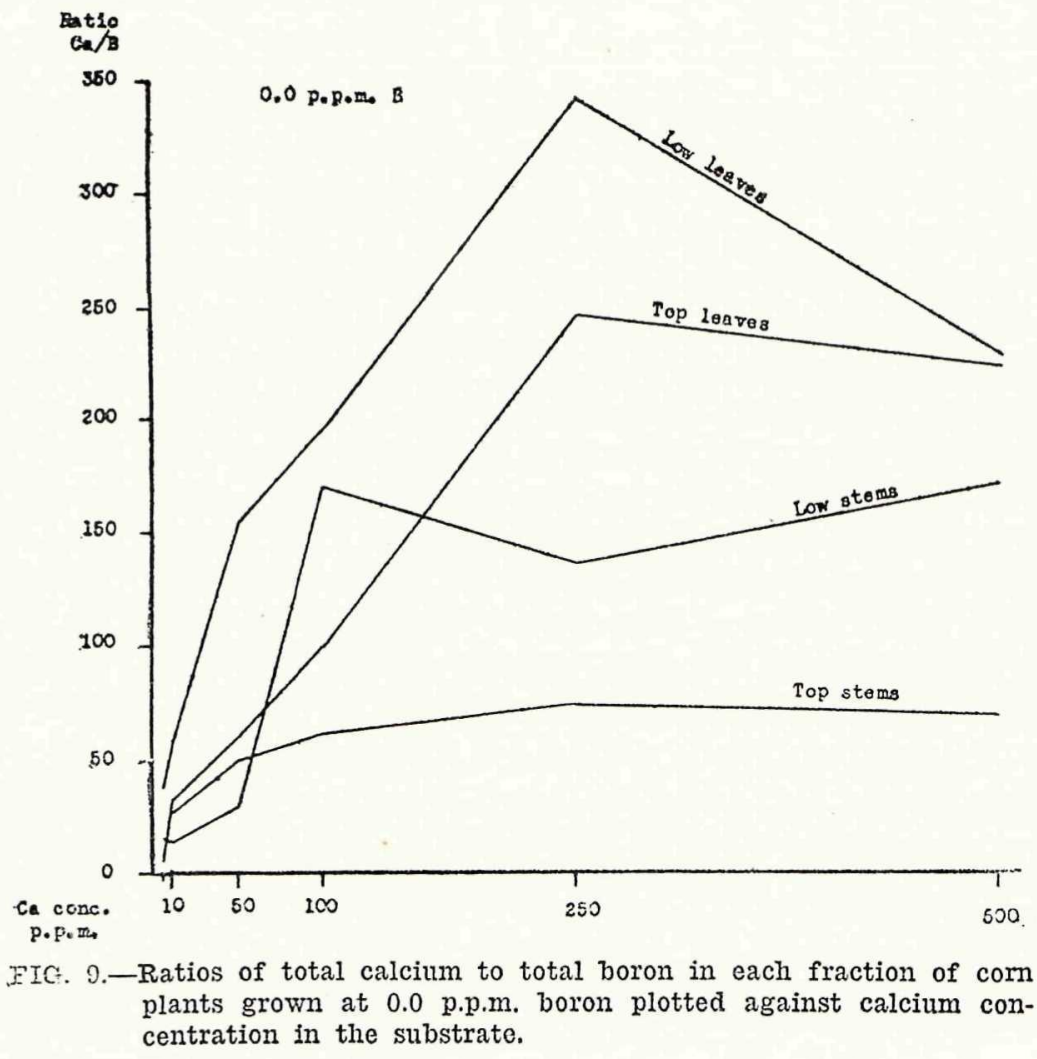


highest boron level (20.0 p.p.m.) at either of the two lowest nutrient levels of calcium respectively (5.0, 10.0 p.p.m.). This, however, was not true in the case of the soluble calcium content of these same tissues; the soluble calcium content being considerably greater in the calcium deficient plants grown at the highest boron level. These differences may be associated with the soluble boron content of the tissues of these calcium deficient plants. Where the soluble calcium content of the tissue was greatest, it was found that the soluble boron content was also the greatest. In other words, the soluble calcium in the top leaves of these calcium deficient plants is not so much a function of the total calcium as it is of the soluble boron. This relation described above did not hold true in the case of the other plant fractions. The same relation between the tissue content of soluble calcium and soluble boron has been obtained by Marsh and Shive (17) for whole tops of calcium deficient corn plants, by Lowenhaupt with the sunflower (16), and by Lorenz with garden beet (15). In general, at a given boron level as the calcium concentration of the substrate increased, there resulted an increased accumulation of total and soluble calcium in each of the various fractionated portions of the plant (47). In general, at a given calcium level, variations in the boron concentrations of the substrate did not influence greatly the calcium content of the tissue of the various plant fractions, except at the two highest calcium levels in the case of the top stems and lower stems where the values of total and soluble ealcium were very high at the highest boron level.

From the analytical data pertaining to the calcium and boron content of the various tissues of the plants grown at various nutrient treatments, the $\mathrm{Ca} / \mathrm{B}$ ratios were calculated in a manner similar to that previously used to determine $\mathrm{Ca} / \mathrm{B}$ ratios for the whole tops. These ratios are presented in table 11 . It is evident that plants showing boron deficient symptoms had the highest $\mathrm{Ca} / \mathrm{B}$ ratios in the various fractionated portions while those giving evidence of boron toxicity and ealcium deficiency had very low $\mathrm{Ca} / \mathrm{B}$ ratios. On the other hand, the plants which did not show any injury and which were apparently healthy had intermediate ratios. The plants which had the greatest green and dry weights, those supplied with 250.0 p.p.m. calcium and 0.25 p.p.m. boron, and which were in ali respects healthy, had a ratio of $\mathrm{Ca} / \mathrm{B}$ of 125 as calculated from the composite sample of the whole tops (table 6 ). The $\mathrm{Ca} / \mathrm{B}$ ratios of the individual tissue fractions of the plants grown with the same nutrient treatments were as follows: top leaves 85; low leaves 194; top stem 62 ; and low stem 77 (table 11). As was to be expected, 


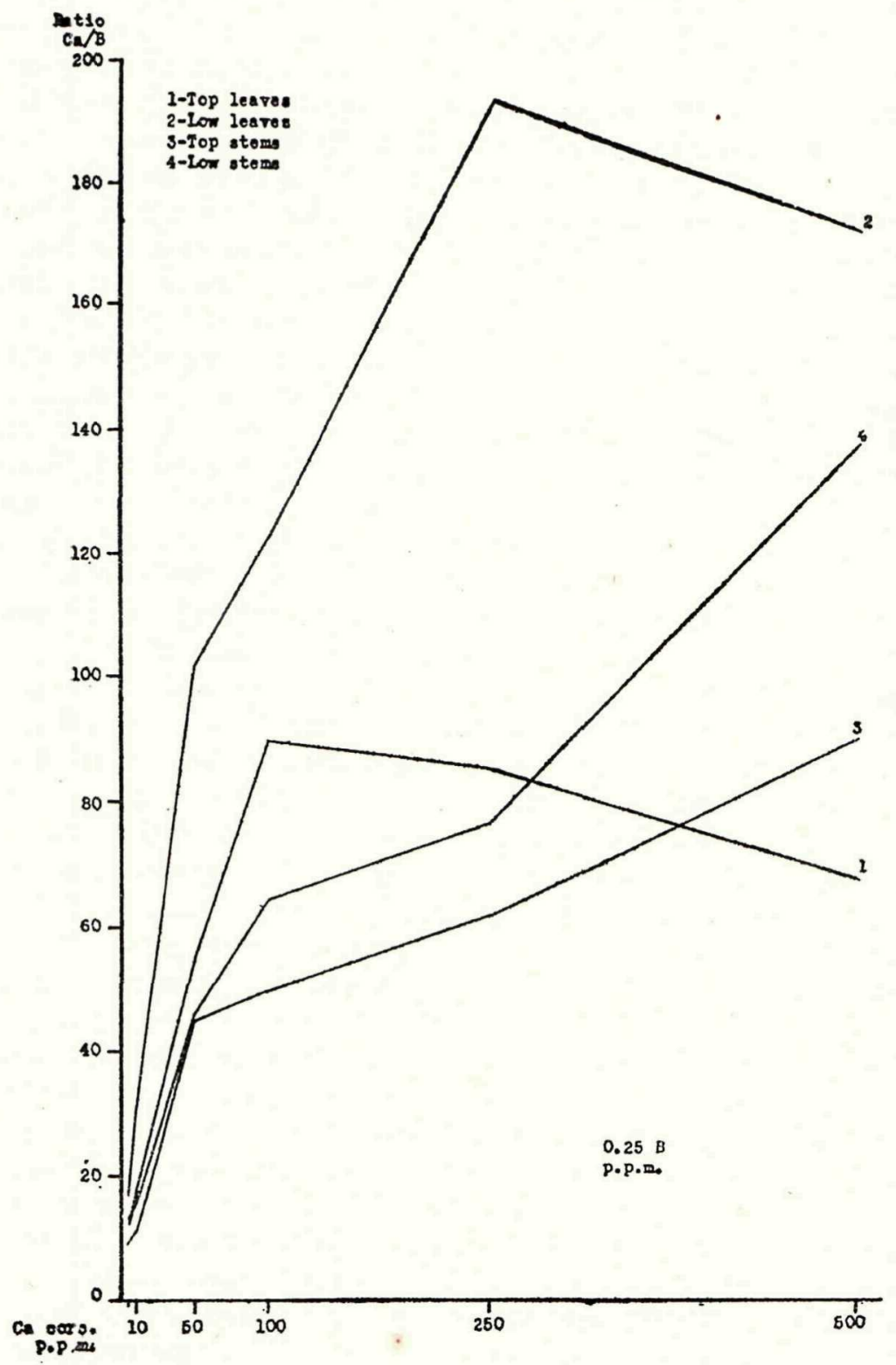

FIG. 10.-Ratios of total calcium to total boron in each fraction of corn plants grown at 0.25 p.p.m. boron plotted against calcium concentration in the substrate. 
because of the greater accumulation of calcium and boron in the older tissues of the plant, the $\mathrm{Ca} / \mathrm{B}$ ratios of the lower leaves were higher than those of the top leaves in all but one case. The same trend followed with regard to the $\mathrm{Ca} / \mathrm{B}$ ratios of the lower stem and the top stem fractions except that at the highest boron concentration there was not much difference between the $\mathrm{Ca} / \mathrm{B}$ ratios of the top and the low stem tissues respectively at any nutrient level of calcium except the highest (500.0 p.p.m.).

As can be seen from table 11 and figures $9,10,11,12$ and 13, as the calcium increased at a given boron level, the $\mathrm{Ca} / \mathrm{B}$ ratio increased in the majority of cases. On the other hand, as the boron increased at a given calcium level, the ratio decreased.

From the analytical results and $\mathrm{Ca} / \mathrm{B}$ ratios presented for both series of corn, it is evident that a certain relationship exists between calcium and boron which affects the metabolism of the corn plant, but which, however, is not so striking as with the tomato $(4,37)$. The quantitative results obtained in the second corn series for the total and soluble boron and calcium contents of the composite samples did not confirm the qualitative observations made, namely, that the boron deficiency symptoms were increasingly severe with increasing calcium concentration of the substrate. However, when a

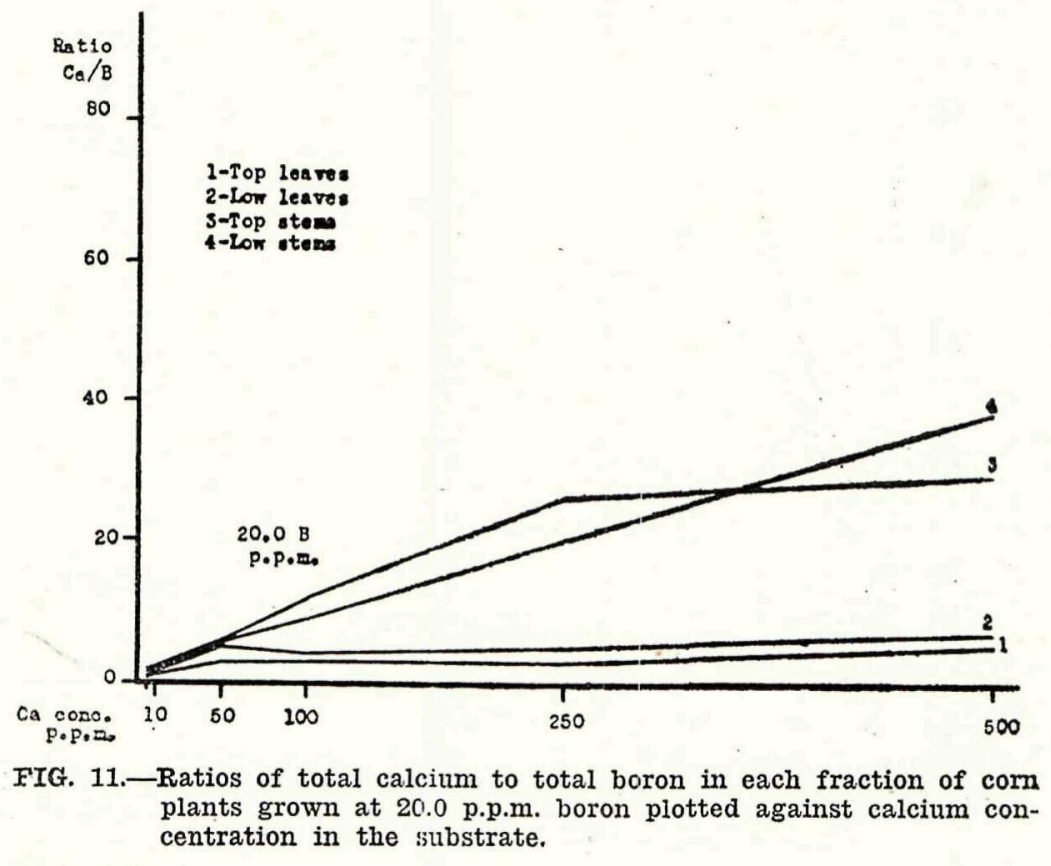


representative plant from the eulture supplied with no boron at the highest calcium levels was fractionated, the analytical results for total and soluble boron for the top leaves were in agreement with the qualitative observations made on the tops of these boron deficient plants. Since a considerable amount of total and soluble boron of these boron deficient plants was found in the older tissues as compared with the top leaves, probably this was the reason why the analytical data of the composite samples did not corroborate the qualitative observations. The higher total and soluble boron of these fractions masked the small amount of total and soluble boron of the top leaves when all the tissues were mixed to take the composite sample, and, therefore, little or no difference was evident between boron contents of whole top samples of different, nutrient treatments. The results further suggest that there is probably little

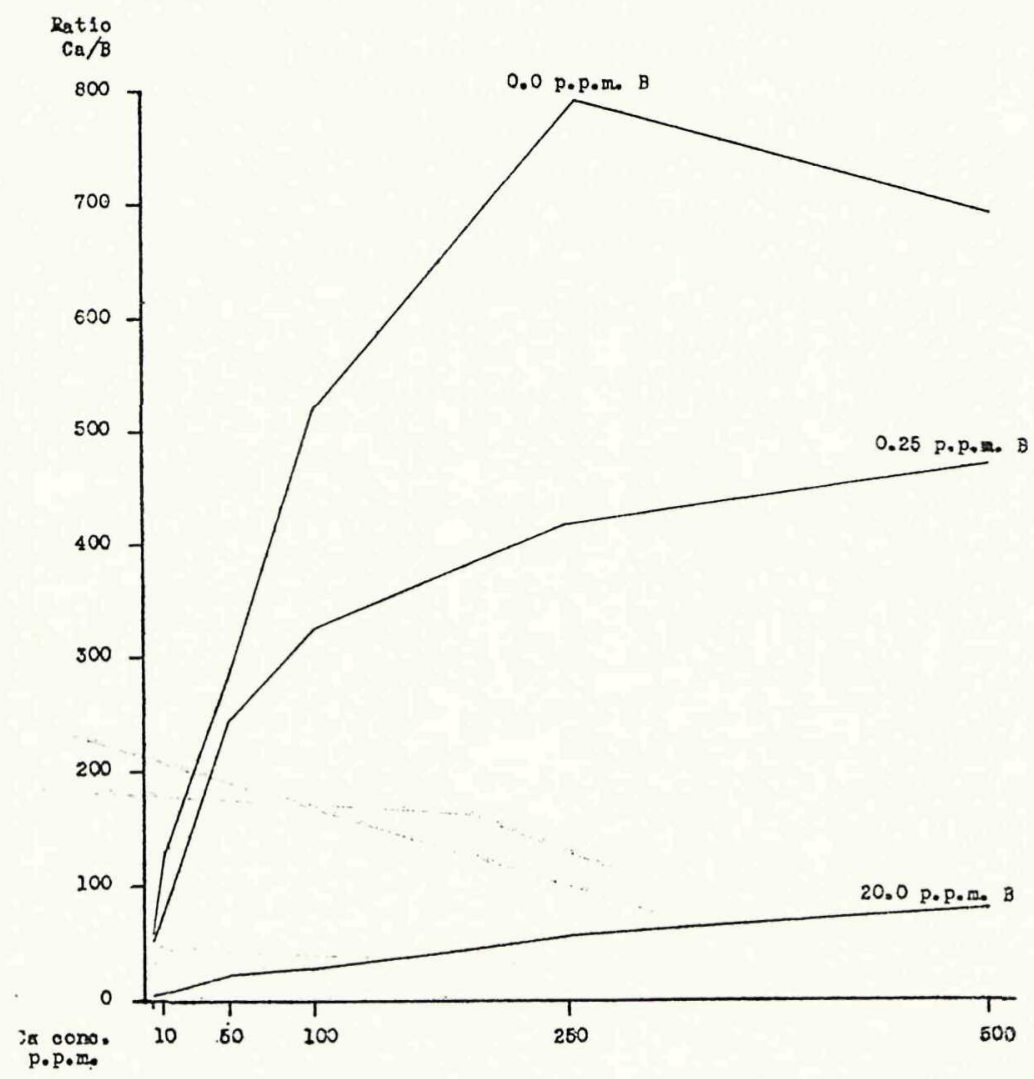

FIG. 12.-Ratios of the averages of tissue contents of total calcium to total boron of the four different plant fractions of corn plants grown at nutrient levels of 0.0, 0.25, and 20.0 p.p.m. 
if any translocation of soluble boron from the older tissues of the boron deficient plants to the 1 op leaves where meristematic activity is at its maximum. It should be mentioned at this point that it took a considerable time for the boron deficiency symptoms to appear in these cultures in both series. However, it took less time than in the similar cultures grown in the fall season (46). The fact that the boron requirements for corn are rather low (18) and that a relatively large proportion of this element is in the soluble state in the plant tissue may explain the late appearance of the injury due to boron deficiency in the top leaves and roots. This also suggests why corn plants made fairly good growth up to the time when the deficiency symptoms appeared. It is probable that the late appearance of boron deficiency symptoms in plants, to which boron was not intentionally supplied, was due in part to the presence of boron as impurities in the salts used. In fact, it was found necessary to repurify one of the salts, namely, $\mathrm{CaCl}_{2}$ for the second series, by recrystalization.

As was pointed out previously, the $\mathrm{Ca} / \mathrm{B}$ ratios of the boron deficient plants were high. Plants that received no boron in the substrate and which were supplied with calcium concentrations of $5.0,10.0$, and 50.0 p.p.m. had a much lower $\mathrm{Ca} / \mathrm{B}$ ratio than those

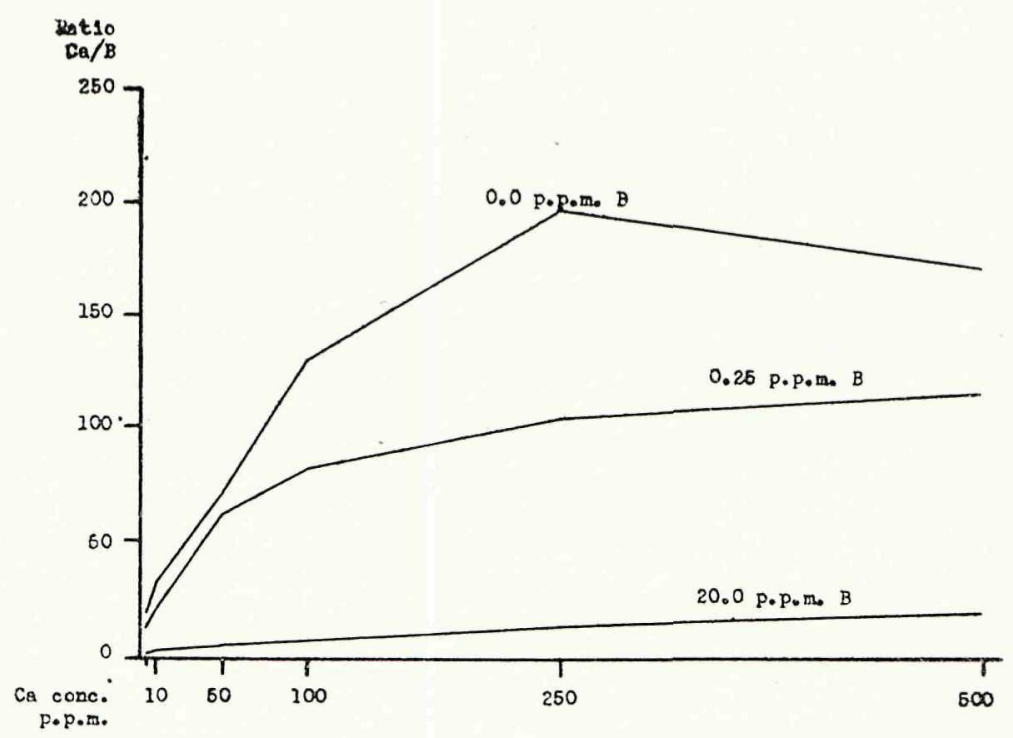

FIG. 13.-Ratios of total calcium to total boron of whole tops of corn plants grown at boron levels of 0.0, 0.25, and 20.0 p.p.m. plotted against calcium concentration in the substrate. 
at the highest calcium nutrient levels and showed either slight boron deficiency symptoms or no symptoms at all. It appears that the combination of high calcium and deficient boron in the substrate upsets the normal metabolism of the plant more seriously than a combination of low calcium and deficient boron.

Neither the quantitative data for total and soluble boron of the composite nor the fractionated portions of the plant confirmed completely the qualitative observations made with regard to a decrease of boron toxicity in the plants supplied with 20.0 p.p.m. boron as the calcium concentration of the substrate increased. On the other hand, the calculated $\mathrm{Ca} / \mathrm{B}$ ratios ior the composite and fractionated portions (table 6 and table 11) of the plants furnish some interesting information. It is in the quantitative relationship between the calcium and boron within the plant that the decrease in the severity of boron toxic symptoms ean be associated. The plants that showed relatively mild boron toxicity symptoms, which were the plants grown with the highest calcium concentrations of the substrate, had higher $\mathrm{Ca} / \mathrm{B}$ ratios than those showing more severe boron toxicity symptoms. This indicates that a combination of high calcium and high boron in the substrate tends to favor a more normal metabolism of the plant than a combination of low calcium and high boron, which brings about a disturbance in the metabolic activities of the plant.

The plants grown in the substrate containing 0.01 to 0.25 p.p.m. boron were devoid of any boron deficiency or boron toxicity symptoms, thus indicating that their metabolism was normal. These plants had $\mathrm{Ca} / \mathrm{B}$ ratios which were intermediate between those of borondeficient and boron-toxic plants.

The quantitative results presented in this report for total and soluble calcium in the corn plant definitely show that the quantitative relationship between these two elements within the plant plays a very important role in the metabolic activities of the plant. Moreover, the data show that a certain balance between calcium and boron must exist within the plant to fulfill the requirements for normal growth and development of this monocotyledon. 


\section{SUMIMARY}

Corn plants were grown in sand culture using the continuous flow method with six different kinds of nutrient solutions which contained different calcium and boron concentrations. A qualitative and quantitative study was made of the response of the plants to the different calcium and boron levels. The results may be summarized as follows:

1. Plants showing symptoms of boron deficiency were found by chemical analyses to have a low content of total and soluble boron and those showing symptoms of boron toxicity a very high content of total and soluble boron.

2. Boron deficient plants were characterized by the appearance of elongated, white transparent stripes in the newly formed leaves. The growth of boron toxic plants was stunted, their top leaves yellow or yellow-green and margins and tips of lower leaves brown and dead.

3. Composite samples of the whole tops of plants showed by analysis that both total boron and soluble boron were largely independent of the calcium concentration in the substrate, except that soluble boron content of the plants grown with the highest boron level (20.0 p.p.m.) was less when supplied with nutrient levels of 500.0 p.p.m. ealcium than with the lower calcium levels.

4. The accumulation of calcium in the composite tissue samples of the tops was found to be largely determined by the calcium concentration in the substrate, except that at the highest nutrient level of boron (20.0 p.p.m.) the calcium content of the tissue of plants grown with high nutrient levels of calcium (100.0, 250.0, 500.0 p.p.m.) was higher than those of plants grown at lower nutrient levels of boron.

5. Boron deficiency symptoms increased in severity with increasing calcium concentration of the substrate throughout the range of the four highest nutrient levels of calcium, except that somewhat more intense boron deficiency symptoms were detected at 250.0 p.p.m. calcium than at 500.0 p.p.m. calcium concentration. Top leaves of boron deficient plants grown at 0.0 p.p.m. boron and which showed boron deficiency symptoms had, in general, lower total and soluble boron content than top leaves of plants grown at the same boron 
level but at the two lowest calcium levels which did not exhibit boron deficiency symptoms. The older tissues of these plants showing external boron deficiency symptoms had a considerably higher total and soluble boron content than the younger tissues (top leaves).

6. The results of this study indicate that there is a limited rate of translocation of boron from the lower portions to the top leaves of boron deficient plants.

7. Boron toxicity decreased in severity with increasing calcium concentration of the substrate.

8. Increasing the concentration of boron in the culture solution resulted in a marked increase of total and soluble boron in all tissues of the plant.

9. There was a greater accumulation of calcium and boron in the older tissues of the plant than in the tissue where meristematic activity was highest.

10. The calcium content of the tissues was determined to a large degree by the calcium concentration of the substrate and was largely independent of the nutrient level of boron.

11. Differences in the soluble calcium contents of the top leaves of calcium deficient plants were related to the soluble boron content of the tissues, which in turn were determined by the boron concentration of the substrate.

12. The quantitative relationship between calcium and boron within the plant plays an important role in the metabolic activities of the plant. Boron deficient plants had a high $\mathrm{Ca} / \mathrm{B}$ ratio, while boron toxic plants had a very low ratio. Plants which apparently were healthy in all respects had intermediate ratios.

13. At a given boron level, inerements in the calcium coneentration in the substrate caused an increase in the $\mathrm{Ca} / \mathrm{B}$ ratio of the tissues.

14. At a given calcium level, increments in the boron concentration in the growth media caused a decrease in the $\mathrm{Ca} / \mathrm{B}$ ratio of the tissues.

\section{ACKNOWLEDGMENT}

Appreciation is expressed to Dr. W. Rei Robbins for his helpful assistance in the preparation of the original material and to Professor Harold E. Clark for his valuable assistance in reviewing and critieizing the manuseript. 


\section{BIBLIOGRAPHY}

1. Association of Official Agricultural Chemists. 1935. Official and Tentative Methods of Analysis. Fourth Edition.

2. Berger, K. C. and Truog, E. 1939. Boron determination in soils and plants using quinalizarin reaction. Ind. and Eng. Chem., Anal. Ed. 11: 540-545.

3. Brenchley, W. E., and Warington, K. 1927. The role of boron in the growth of plants. Ann. Bot. 41: 167-187.

4. Brennan, Eileen G. 1946. The relation between ealeium and boron in the distribution of these elements in the tomato. Thesis submitted to the Graduate Faculty of Rutgers University in partial fulfillment of the requirements for the degree of Master of Science.

5. Cook, R. L., and Millar, C. E. 1939. Some soil factors affecting boron availability. Soil Sci. Soc. Amer. Proc., 4:297-301.

6. Drake, M., Sielling, D. H., and Scarseth, C. D. 1941. Caleium-boron ratio as an important factor in controlling boron starvation. J. Amer. Soc. Agron. 33:454-462.

7. Dmitriev, K. A. 1938. A new method of increasing yield of red elover. Probl. Zhivotnov., 5:182-185. (Abs. in Soils and Fert., 2:3, 133. 1939).

8. Eaton, F. 1944. Deficiency, toxicity, accumulation of boron in plants. J. Agr. Res. 69: No. 6:237-277.

9. Gum, Oren B., Brown, H. D., and Burrell, R. C. 1945. Some effects of boron and manganese in the quality of beets and tomatoes. Plant Physiol. 20:267-275.

10. Haas, A. R. C. 1929. Toxic effect of boron on fruit trees. Bot. Gaz. 88:113-131.

11. Haas, A. R. C. 1945. Boron in citrus trees. Plant Physiol. 20:323-343.

12. Hill, H., and Grant, E. P. 1935. The growth of turnips in artificial cultures. Sci. Agr. 15:6.52-659.

13. Holley, K. T., and Dulin, T. G. 1937. A study of ammonia and nitrate nitrogen for cotton. IV. Influence of boron concentration. Ga. Exp. Sta. Bul. 197.

14. Jones, H. E. and Scarseth, G. D. 1944. The calcium-boron balance in plants as related to boron needs. Soil Sci. 57:15-24.

15. Lorenz, O. A. 1941. Relation between boron and ealcium in growth of garden beet. Proc. Amer. Soc. Hort. Sei. 39:368.

16. Lowenhaupt, B. 1942. Nutritional effects of boron on growth and development of the sunflower. Bot. Gaz. 104:316-322.

17. Marsh, R. P. and Shive, J. W. 1941. Boron as a factor in the ealcium metabolism of the corn plant. Soil Sei. 51:141-151.

18. Marsh, R. P. 1942. Comparative study of the calcium-boron metabolism of representative dicots and monocots. Soil Sci. 53:75-78. 
19. McLean, R. C. and Hughes, W. L. 1936. Quantitative distribution. of boron in Vicia faba and Gossypium herbacum. Ann. Appl. Biol. 23: 231-244.

20. Midley, A. R. and Dunklee, D. E. 1939. The effect of lime on the function of borates in the soil. Soil Sci. Amer. Proc. 4:302-307.

21. Minarik, C. E. and Shive, J. W. 1939. The effect of boron on the substrate on calcium accumulation by soybean plants. Amer. Jour. Bot. $26: 827-831$.

22. Morris, A. A. 1938. Effects of boron treatment in the control of hard fruit in eitrus. Jour. Pom. Hort. Sei. 16:167-181.

23. Muckenhirn, R. J. 1936. Response of plants to boron, copper, and manganese. Jour. Amer. Soc. Agron. 28:824-842.

24. Muhr, G. R. 1942. Plant symptoms of boron deficiency and effects of borax on the yield and chemical composition of several erops. Soil Sei. $54: 55$.

25. Naftel, J. A. 1937. Soil-liming investigation: V. The relation of boron deficiency to over-liming injury. Jour. Amer. Soc. Agron. 29:761-771.

26. Naftel, J. A. 1937. The influence of excessive liming on boron deficiency in soils. Soil Sei. Soe. Amer. Proc. 2:383-384.

27. Naftel, J. A. 1938. Recent studies on boron in soils. The Amer. Fertilizer, Vơl. 89:6-5, 24, 26.

28. Naftel, J. A. 1942. Soil-liming investigations. VI. Response of Crimson Clover to boron with and without lime on coastal plain soils. Jour. Amer. Soc. Agron. 34:975-985.

29. New Jersey Agricultural Exp. Sta. 1937. Level of the boron supply in relation to nitrogen metabolism in cotton. N. J. Agr. Exp. Sta. Ann. Rpt. pp. 84-85.

30. Nightingale, G. T., Addams, R. M., Robbins, W. R., and Schermerhorn, L. G. 1931. Effect of calcium deficiency on nitrate absorption and on metabolism in tomato plant. Plant Physiol. 6:605-627.

31. Parks, R. Q., Lyon, C. B., and Hood, I. L. 1944. Some effects of boron supply on the chemical composition of tomato leaflets. Plant Physiol. $19: 404-419$.

32. Powers, W. L. 1939. Boron and soil fertility in Pacific Northwest. Proc. Soil Sei. Soe. Amer. 4:290-296.

33. Powers, W. I. 1941. Boron-a minor plant nutrient of major importance. Better Crops with Plant Food 12 (6):17-19, 36-37.

34. Purvis, E. R. and Hanna, W. J. 1938. Boron Studies: I. The susceptibility of various plants to boron toxicity as influeneed by soil type. Soil Sei. Soc. Amer. Proc. 3:205-209.

35. Purvis, E. R. 1940. The present status of boron in American agriculture. Soil Sei. Soc. Amer. Proc. 4:316-321.

36. Reeve, E. 1943. Boron as a factor in the potassium and calcium metabolism of plants. Thesis submitted to the Graduate Faculty of Rutgers University in partial fulfilment of the requirements for the degree of Doctor of Philosophy. 
37. Reeve, E. and Shive, J. W. 1944. Potassium-boron and calcium-boron relationships in plant nutrition. Soil Sci, 57:1-14.

38. Shive, J. W. 1941. Significant roles of trace elements in the nutrition of plants. Plant Physiol. 16:435-445.

39. Shive, J. W. and Robbins, W. R. 1942. Methods of growing plants in solution and sand cultur's. N. J. Agr. Exp. Sta. Bul. 636.

40. Shive, J. W. and Stahl, A. L. 1927. Constant rate of continuous solution renewal for plants in water cultures. Bot. Gaz. 84:317-323.

41. Shive, J. W. 1945. Boron in plant life-A brief historical survey. Soil Sci. 6:41-51.

42. Sommer, A. I. and Lipman, C. B. 1926. Evidence of the indispensable nature of zinc and boron for higher green plants. Plant Physiol. $1: 231-249$.

43. Sommer, A. L. 1927. The search for elements essential in only small amounts for plant growth. Sei. 66:482-484.

44. Van Overbeek, J. 1934. Symptoms of boron deficiency in Zea Mays. Bibliography of reference to literature on minor elements. Third Ed. L. G. Willis p. 59.

45. Wallace, T. 1943. The diagnosis of mineral deficiencies in plants by visual symptoms. A color atlas and guide. London, H. M. Stationary Office.

46. Waringtor, K. 1933. The influence of length of day on the response of plants to boron. Ann. Bot. 47:429-458.

47. Warington, $\mathbf{K}$. 1934. Studies on absorption of calcium from nutrient solutions with special references to presence or absence of boron. Ann. Bot. 48:743-776.

48. Whetstone, R. R., Robinson, W. O., and Byers, H. G. 1942. Boron distribution in soils and related data. U.S.D. A. Bur. Plant Indus. Tech. Bul. 797 .

49. White-Stevens, R. H. 1941. Limits in the use of boron in the production of certain vegetal.le crops. Proc. of Amer. Soc. Hort. Sci. 39:367.

50. Wolf, B. 1939. Experiments with boron on some New Jersey soils. Soil Sci. $48: 41-57$.

51. Wolf, B. 1940. Factors infiueneing availability of boron in soil and its distribution in plants. Soil Sci. 50:20y-217. 
Genaral Supplies Administration

Servicz Offick of the Govirnanest of Pugrto Rico

Printing Division

1950 